\title{
Transformation of agricultural landscapes in the Anthropocene: Nature's contributions to people, agriculture and food security
}

\author{
Adam J. Vanbergen ${ }^{\mathrm{a}, *}$, Marcelo A. Aizen ${ }^{\mathrm{b}}$, Stephane Cordeau ${ }^{\mathrm{a}}$, \\ Lucas A. Garibaldi ${ }^{c, d}$, Michael P.D. Garratt ${ }^{\mathrm{e}}$, \\ Anikó Kovács-Hostyánszki ${ }^{f}$, Lou Lecuyer ${ }^{\mathrm{a}}$, Hien T. $\mathrm{Ngo}^{\mathrm{g}}$, \\ Simon G. Potts ${ }^{\mathrm{e}}$, Josef Settele ${ }^{\mathrm{h}, \mathrm{i}, \mathrm{j}}$, Eirini Skrimizea ${ }^{\mathrm{a}}$, and \\ Juliette C. Young ${ }^{\mathrm{a}, \mathrm{k}}$ \\ ${ }^{a}$ Agroécologie, AgroSup Dijon, INRAE, Université de Bourgogne Franche-Comté, Dijon, France \\ ${ }^{\mathrm{b}}$ Instituto de Investigaciones en Biodiversidad y Medioambiente (INIBIOMA), Universidad Nacional del \\ Comahue-CONICET, San Carlos de Bariloche, Rio Negro, Argentina \\ ${ }^{c}$ Universidad Nacional de Río Negro, Instituto de Investigaciones en Recursos Naturales, Agroecología y \\ Desarrollo Rural, San Carlos de Bariloche, Río Negro, Argentina \\ ${ }^{\mathrm{d} C o n s e j o ~ N a c i o n a l ~ d e ~ I n v e s t i g a c i o n e s ~ C i e n t i ́ f i c a s ~ y ~ T e ́ c n i c a s, ~ I n s t i t u t o ~ d e ~ I n v e s t i g a c i o n e s ~ e n ~ R e c u r s o s ~}$ \\ Naturales, Agroecología y Desarrollo Rural, San Carlos de Bariloche, Río Negro, Argentina \\ ${ }^{\mathrm{e}}$ Centre for Agri-Environmental Research, School of Agriculture, Policy and Development, Reading \\ University, Reading, United Kingdom \\ ${ }^{\mathrm{f}}$ Centre for Ecological Research, Institute of Ecology and Botany, Vácrátót, Hungary \\ ${ }^{\mathrm{g}}$ Intergovernmental Science-Policy Platform on Biodiversity and Ecosystem Services (IPBES), Bonn, Germany \\ ${ }^{\mathrm{h}}$ Department of Community Ecology, Helmholtz Centre for Environmental Research, UFZ, Halle, Germany \\ ${ }^{i}$ iDiv, German Centre for Integrative Biodiversity Research, Halle-Jena-Leipzig, Leipzig, Germany \\ ${ }^{\mathrm{j}}$ Institute of Biological Sciences, College of Arts and Sciences, University of the Philippines, College, Los Baños, \\ Laguna, Philippines \\ ${ }^{\mathrm{k}}$ UK Centre for Ecology \& Hydrology, Penicuik, Midlothian, United Kingdom \\ *Corresponding author: e-mail address: adam.vanbergen@inrae.fr
}

\section{Contents}

1. Introduction

2. Indirect drivers of change in contemporary agricultural landscapes

3. Agriculture: A direct driver of landscape structure, biodiversity and ecosystem services

4. Alternative management approaches to conventional intensive agriculture

4.1 Optimisation of production through increased efficiency

4.2 Substitution of external inputs or environmentally harmful procedures

4.3 Farming system redesign and nature-based approaches

5. Key issues affecting the transition to sustainable agricultural landscapes

5.1 Social dimensions at the centre of agricultural transformations

5.2 Emerging biotechnologies for crop breeding and novel foods

5.3 The economic scale and ecological state of the farming system 
6. Conclusions

\section{Abstract}

Multiple anthropogenic challenges threaten nature's contributions to human well-being. Agricultural expansion and conventional intensification are degrading biodiversity and ecosystem functions, thereby undermining the natural foundations on which agriculture is itself built. Averting the worst effects of global environmental change and assuring ecosystem benefits, requires a transformation of agriculture. Alternative agricultural systems to conventional intensification exist, ranging from adjustments to efficiency (e.g. sustainable intensification) to a redesign (e.g. ecological intensification, climate-smart agriculture) of the farm management system. These alternatives vary in their reliance on nature or technology, the level of systemic change required to operate, and impacts on biodiversity, landscapes and agricultural production. Different socio-economic, ecological and political settings mean there is no universal solution, instead there are a suite of interoperable practices that can be adapted to different contexts to maximise efficiency, sustainability and resilience. Social, economic, technological and demographic issues will influence the form of sustainable agriculture and effects on landscapes and biodiversity. These include: (1) the socio-technical-ecological architecture of agricultural and food systems and trends such as urbanisation in affecting the mode of production, diets, lifestyles and attitudes; (2) emerging technologies, such as gene editing, synthetic biology and 3D bioprinting of meat; and (3) the scale or state of the existing farm system, especially pertinent for smallholder agriculture. Agricultural transformation will require multifunctional landscape planning with cross-sectoral and participatory management to avoid unintended consequences and ultimately depends on people's capacity to accept new ways of operating in response to the current environmental crisis.

\section{Introduction}

Nature provides multiple and diverse contributions, including biodiversity and ecosystem goods and services, to the support and well-being of the global human population (Díaz et al., 2018; IPBES, 2019; Potts et al., 2016). At the same time, marking the shift towards a new epoch, the Anthropocene (Ellis et al., 2010; Steffen et al., 2011), the Earth is undergoing rapid anthropogenic environmental challenges, including climate change, modification or degradation of ecosystems and a global biodiversity extinction crisis (IPBES, 2019; IPCC, 2019). These changes constitute a planetary-scale crisis due to the growing erosion or elimination of nature and its contributions to well-being, such as stable ecosystem functioning, nutritional security and provision of clean air and water, food and energy 
(Chaplin-Kramer et al., 2019; Dirzo et al., 2014; IPBES, 2019; McGill et al., 2015; Potts et al., 2016; Wall et al., 2015).

A suite of interacting, socio-cultural and economic drivers directly and indirectly modifies the supply of ecosystem goods and services from nature (IPBES, 2016, 2019). Globally, the human population is projected to grow to 9.7 billion up to 2050 until plateauing around 11 billion in 2100 (UN, 2019). In addition, increased per capita consumption alongside continuing income and economic inequality within and across world regions is expected. Following such a trajectory will risk further environmental degradation and a failure to meet current and future policy objectives, such as the Sustainable Development Goals of the 2030 Agenda for Sustainable Development, the Aichi Biodiversity Targets and the CBD post-2020 Global Biodiversity Framework, aiming at improving human well-being and preserving the biosphere (CBD, 2014; IPBES, 2019; UN, 2015).

Land-use change is consistently the principal direct driver of changes in habitat cover on approximately half of the Earth's terrestrial surface (Ellis et al., 2010; Foley et al., 2005; IPBES, 2019; Newbold et al., 2016). The interplay between land-use (e.g. natural resource extraction, habitat conversion and food production) and the state and processes of the natural ecosystem (e.g. geomorphology, climate, biological functions) form landscapes. Of the many environmental goods that humans obtain from nature, agriculture and the production of food continues to be the major factor shaping the world's landscapes (IPBES, 2019; IPCC, 2019). For example, as of 2017 the total production of cereal crops had increased $240 \%$ relative to the 1961 baseline (IPCC, 2019) driven by a combination of high-yielding crop varieties, intensive management, and arable land expansion at the expense of semi-natural habitats (Ellis et al., 2010; Foley et al., 2005; IPBES, 2019).

Agricultural expansion and habitat conversion is the most widespread form of land-use change, and coupled to conventional intensive agricultural management, currently represents the main approach to assuring food supply (IPBES, 2016, 2019). Conventional intensive agriculture is the prevailing food production paradigm and is characterised by industrial management of livestock or large-scale monocultures with high external inputs and mechanisation that circumvent many of the ecosystem limits to production (Godfray et al., 2010; Kovács-Hostyánszki et al., 2017; Pretty, 2018). In this manner, conventional intensive management and agricultural expansion has been profoundly successful at delivering increased yields and food security (Godfray et al., 2010; Piesse and Thirtle, 2010; Pretty, 2018; Qaim, 2017); although significant nutritional deficits and asymmetries in access 


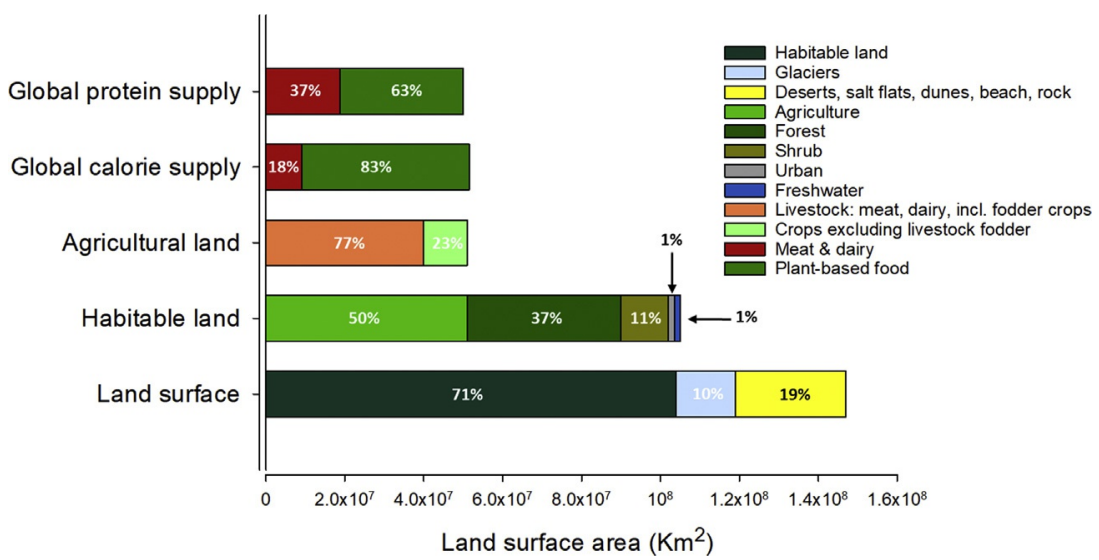

Fig. 1 Percentage cover of the terrestrial surface by broad classes of habitat and landuse. Original data are millions of $\mathrm{km}^{2}$ and sourced from the UN FAO, redrawn and modified from OurWorldinData.org (CC-BY Haan Ritchie \& Max Roser, 2019).

to food remain in large parts of the world marked by structural poverty (IPBES, 2019; Willett et al., 2019).

The appropriation of up to $50 \%$ the Earth's land-surface for cropping or livestock production (Ellis et al., 2010; IPBES, 2019) (Fig. 1), has altered landscapes, and is the predominant pressure on biodiversity and environmental goods and services supporting human well-being (Aizen et al., 2019; IPBES, 2019; Newbold et al., 2016; Potts et al., 2016). This reliance of agriculture on beneficial biodiversity and ecosystem processes and the fact that this socio-cultural and industrial practice is itself a major cause of ecosystem degradation and biodiversity extinction, means that agricultural reform is a necessity for shaping future food production, landscape structure, and societal responses to the current environmental crisis.

A societal consensus is emerging that to forestall the worst effects of global environmental change, while continuing to feed a growing and economically developing human population, transformative and systemic changes are required to move to a sustainable agricultural management (Bommarco et al., 2013; Godfray et al., 2010; IPBES, 2019; Kleijn et al., 2019; Pretty, 2018; Rockstrom et al., 2017; Tittonell, 2014). The world is a heterogeneous place ecologically, socio-culturally and economically but there are evident risks of 'biotic homogenization' (IPBES, 2019). Assuring food and nutritional security whilst restoring and maintaining ecological and ecosystem functioning will require a suite of options that deliver these objectives in the most optimal and socially-just way for particular 
geographical, socioecological, and societal contexts and scales (Godfray et al., 2010; IPBES, 2019; Rockstrom et al., 2017; Tittonell, 2014).

There is an array of technological and farming approaches, available or developing, that might assure the stability of agricultural production whilst meeting the challenge of moving to a sustainable food system. These include farm management approaches that differ according to their dependence on existing or emerging technologies - e.g., precision agriculture (Pretty, 1997, 2018; Wolfert et al., 2017), genetic modification (Altpeter et al., 2016; Chen et al., 2019; Ort et al., 2015), synthetic biology and alternative proteins (Mattick et al., 2012; Mouat et al., 2019; Stephens, 2013)_or in harnessing knowledge about natural ecosystem processes in support of agricultural production (Bommarco et al., 2013; Garibaldi et al., 2019; Kleijn et al., 2019; Rockstrom et al., 2017). Such changes in the agricultural system will also depend on the farmers' socio-cultural and institutional context, capacity or willingness to adapt, and trade-offs between their worldviews and those of other societal actors (Marshall et al., 2014; Martin et al., 2018; Moser and Ekstrom, 2010; Vermeulen et al., 2018). The form that a sustainable agriculture takes will also be influenced by the socio-economic scale and ecological state of the existing agricultural system (Hill et al., 2019; Lowder et al., 2019; Zimmerer et al., 2015) and the social and environmental changes precipitated by increasing urbanisation worldwide (Horst et al., 2017; IPBES, 2019; Orsini et al., 2013). Therefore, the choice between adopting either nature-based farm management or agri-technological solutions has profound socio-ecological considerations and implications for future sustainable landscapes, biodiversity and the balance of ecosystem services and disservices they provide (Fig. 2).

In this chapter, we outline the indirect drivers that create contemporary agricultural landscapes (Section 2). We then discuss the ways that contemporary agricultural systems form landscapes and shape ecosystem services and disservices (Section 3). Next, we discuss alternative models of agriculture being debated, advocated, developed or implemented as part of current efforts to improve agricultural sustainability (Section 4). We then examine some key issues that influence the transition to a sustainable agriculture: the social dimensions of transformative changes in agriculture and food system sustainability (Section 5) using the example of urbanisation (Section 5.1.1), emerging technologies for novel crops and foods (Section 5.2) and the economic scale and ecological state of the farming system (Section 5.3). We conclude with a discussion of how nature-based, technological or policy responses could profoundly change how the world obtains food and nutrition and the consequences for the crisis in biodiversity and ecosystem function (Section 6). 


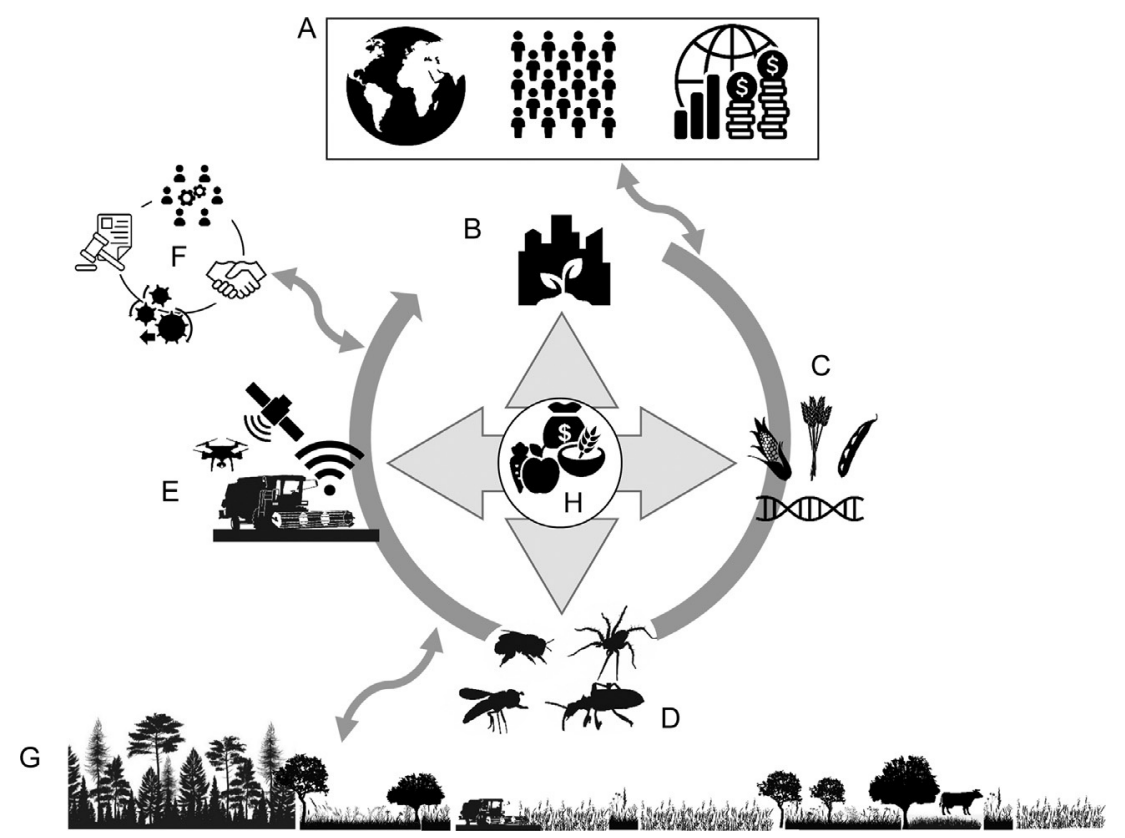

Fig. 2 Conceptual diagram linking the (A) direct and indirect drivers of global change, human population growth, economic development and consumption with (B-E) alternative and potentially interoperable agricultural systems, ranging from (B) urban agriculture, $(C)$ biotechnology and synthetic biology, (D) nature-based ecological intensification and (E) sustainable precision and SMART agriculture. The precise form and combinations of agricultural alternatives (B-E) and their implementation depends crucially on a (F) multi-stakeholder, participatory process and dialogue to deliver major restructuring of the policy, industrial and business sectors tailoring the alternative system to local and/or global contexts. Such a process aims to produce $(G)$ multifunctional and ecologically heterogeneous agroecosystems and landscapes that deliver $(\mathrm{H})$ food, nutritional and financial security alongside restoration of (D) biodiversity and ecosystem services and ( $\mathrm{A}$ and $\mathrm{H})$ nature's contributions to people. Images sourced from shutterstock. com (free trial) and the nounproject.com (CC: Eucalyp, Jason Gray, Priyanka, Vectors point, Vincencio, Guillermo Vera, Amy Morgan, Lars Meiertoberens, Adrien Coquet, Maxim Kulikov, Arafat Uddin, Hawraa Alsalman; public domain: James Keuning, Grace Communications Foundation and Mother Jones).

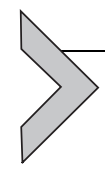

\section{Indirect drivers of change in contemporary agricultural landscapes}

Agricultural landscapes are the product of the interplay between multiple, mostly anthropogenic, drivers that directly (proximate causes) or indirectly (underlying causes) influence the composition and distribution of 
land-use. Because agriculture is both a societal and industrial practice, agricultural landscape structure is impacted indirectly by demographic, sociocultural, economic, technological and institutional factors governing food production (IPBES, 2019). Over the last 50 years, the growing human population coupled to policies and technological advances that have facilitated rapid economic growth and globalised trade and commerce have profoundly altered consumption and production patterns at all scales (Godfray et al., 2010; IPBES, 2019; Qaim, 2017). This complex interaction among these underlying conditions has led, in many regions of the world, to agricultural expansion and the adoption of conventional intensive agricultural management, either to feed regional populations or to produce commodities for geographically distant markets on a global scale (Godfray et al., 2010; IPBES, 2019). This widespread shift to an industrial agriculture has tripled global agricultural crop production since 1970, which alongside globalised trade in agricultural commodities and products, has produced substantial economic gains, but also with costs of biodiversity loss and highly modified and simplified landscapes (Godfray et al., 2010; IPBES, 2019; Piesse and Thirtle, 2010; Pretty, 2018).

Urbanisation is another major social, economic and demographic trend with consequences for the structure and function of agricultural landscapes. Currently, urban land only represents $1 \%$ of the habitable land (Fig. 1), but urbanisation of the human population is predicted to increase globally, especially in parts of Africa and Asia that are some of the world's most productive croplands (d'Amour et al., 2017; IPBES, 2019). Urbanisation brings risks and opportunities for agriculture, ecosystems and landscapes (Section 5.1.1). It creates challenges for the production and distribution of food and livelihood instability in already vulnerable regions of the world (IPBES, 2019). Urbanisation also distances the human population from the site and process of food production altering social and ethical attitudes pertaining to farming and the use or preservation of nature. It creates a societal debate over which modes of agriculture or food production (see Section 4) can or should be adopted, the dietary expectations or choices of people, and, according to their social and economic acceptability, where the site of different forms of food production should be located (Section 5.1.1). Such changes to the human lifestyles and population distribution coupled to the need for climate change adaptation (Section 4.3.2) raise the prospect of profound changes in land-use that overlap with the potential for land sparing (see chapter "Combining land-sparing and land-sharing in European landscapes" by Grass et al., in press), rewilding and restoration 
of biodiversity and good ecosystem functioning (IPBES, 2019; Navarro and Pereira, 2012; Tscharntke et al., 2012).

Another crucial dimension that shapes farming, landscape structure and ecosystems is the capacity and willingness of farmers to adapt to changes in the environment, economy and social expectations by altering the goal or location of their activity (Moser and Ekstrom, 2010; Vermeulen et al., 2018). Those farmer decisions depend on technical or market considerations, and are also deeply embedded in farmer identity (Marshall et al., 2014) and the wider agricultural, institutional and economic contexts that create opportunities, incentives or limitations to adaptation (Dowd et al., 2014; Martin et al., 2018; Park et al., 2012; Vermeulen et al., 2018). Farmer decisions, incorporating their views and priorities on farming practices, the environment, social norms and their roles and responsibilities may conflict with other actors such as urban dwellers, authorities or other rural inhabitants (Mann and Jeanneaux, 2009) (see chapter "Sustainable agriculture: Recognizing the potential of conflict as a positive driver for transformative change" by Skrimizea et al., this volume). Considering the social (including economic) dimensions of agriculture are therefore central to the transformation to a sustainable agricultural system and the future structure and functioning of the landscape (Section 5).

\section{Agriculture: A direct driver of landscape structure, biodiversity and ecosystem services}

Conventional intensive agricultural management is itself a multifactorial direct driver of change in biodiversity and ecosystem function (IPBES, 2019; Potts et al., 2016). Through the industrial-scale management of livestock and large-scale monocultures in simplified rotations reliant on high levels of agrichemicals (synthetic fertilisers, insecticides, herbicides, fungicides), this type of farm management homogenises landscape habitat structure to produce a highly simplified ecosystem (Garibaldi et al., 2017; Kovács-Hostyánszki et al., 2017). Aside from habitat loss, further impacts on non-target biota occur through the impacts of agrichemicals, both in terms of direct (e.g. toxic and sub-lethal effects of pesticides) and indirect effects (ecological community shifts elicited by herbicides) (Chagnon et al., 2015; Godfray et al., 2014; Kovács-Hostyánszki et al., 2017; Pisa et al., 2015). In this manner, the effects of conventional intensive agriculture act as an environmental filter leading to the homogenisation of biological communities by extirpating many species and interactions. Only those 
species with traits that pre-adapt them to exploit (e.g. r-selected insects, resistant biotypes) or tolerate (e.g. mobile, generalist omnivore) the highly anthropogenic farmed landscape persist (Bommarco et al., 2010; Burkle et al., 2013; Dainese et al., 2019; de Vries et al., 2013; IPBES, 2019; Marini et al., 2014; Martin et al., 2019; Redhead et al., 2018; Tsiafouli et al., 2015; Wall et al., 2015).

These effects of agricultural expansion and conventional intensive management have directly impacted the organisms that provide services underpinning crop production itself-namely pollination, pest regulation and a number of soil services (Chaplin-Kramer et al., 2019; Dainese et al., 2019; Potts et al., 2016; Tscharntke et al., 2012; Wall et al., 2015) (Fig. 3).

Pollinators are one important example of how functional groups of organisms can help to safeguard crop yields and wild plant reproduction

A

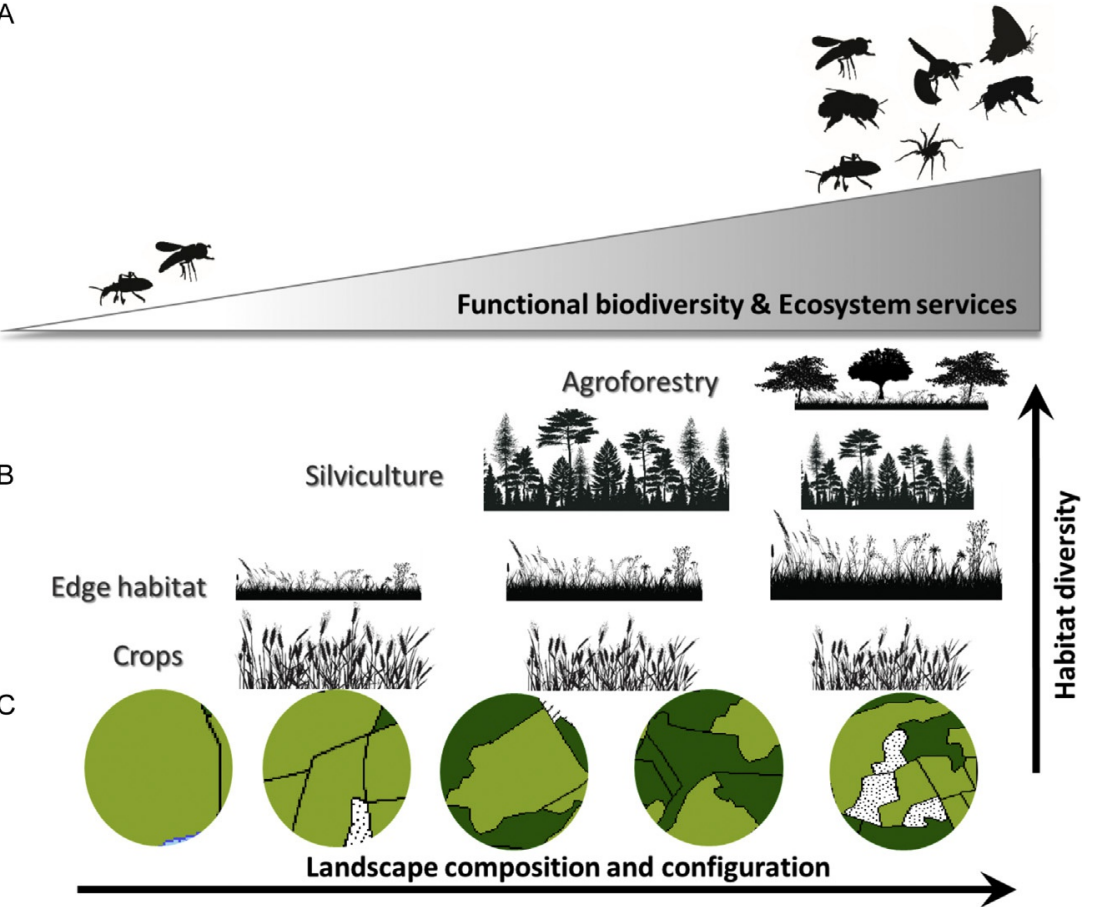

Fig. 3 The relationship between (A) functional biodiversity delivering ecosystem services (e.g. pollination, natural biocontrol) in support of crop yields and (B) the diversity of habitats along a $(C)$ gradient of landscape composition and configuration ranging structurally simple monocultures to diverse habitat-crop mosaics with high edge (ecotone) densities facilitating maximum spill over of services. Images sourced from shutterstock.com (free trial) and the nounproject.com (public domain: James Keuning). 
(Potts et al., 2016). Managed pollinators, such as the western honeybee, are important providers of pollination services for certain plant taxa or in already highly intensified systems (Hung et al., 2018; Potts et al., 2016; Rollin and Garibaldi, 2019; Woodcock et al., 2013). Complete reliance on one or a small number of managed pollinators for crop pollination is risky, however, due to the threats from pests and pathogens causing bee diseases (Potts et al., 2016; Vanbergen et al., 2018) and mismatches in supply and demand that may create pollination deficits (Breeze et al., 2014). However, wild pollinators have been shown to be important crop flower visitors (Hung et al., 2018; Potts et al., 2016; Rader et al., 2016) that safeguard fruit set even in the presence of managed bees (Garibaldi et al., 2013). Most crop pollination is provided by a small number of dominant (i.e. highly abundant) species (Dainese et al., 2019; Kleijn et al., 2015; Winfree et al., 2015). Diverse pollinator communities, however, usually better support crop pollination and crop quality (see chapter "Invasive bees and their impact on agriculture" by Aizen et al., this volume) through species complementarity over space or time and among crop species (Brittain et al., 2013; Dainese et al., 2019; Greenleaf and Kremen, 2006; Hoehn et al., 2008; Winfree et al., 2018; Woodcock et al., 2019). This may be due to 'response diversity'differential responses to the same environmental perturbations-which increases the overall stability of the pollination service in the face of environmental variability or global change (Martin et al., 2019; Winfree and Kremen, 2009). Alternatively, it may be because diverse wild pollinator assemblages elevate or facilitate cross-pollination rates via greater overall activity or behavioural or functional complementarity arising from species trait diversity (Brittain et al., 2013; Garibaldi et al., 2013, 2015; Hoehn et al., 2008; Woodcock et al., 2013).

In a similar way, the abundance or diversity of natural enemies, such as predatory or parasitic arthropods, can indirectly support crop production by suppressing populations of invertebrate pests (Letourneau et al., 2009; Liere et al., 2015; Redlich et al., 2018; Shackelford et al., 2013). Biodiversity is also key to a healthy and functioning soil. Plant-soil biota interactions, abundance of key soil functional groups, and soil food web complexity are all directly linked to the delivery and resilience of soil ecosystem functions underpinning plant/crop productivity (Bender et al., 2016; Blouin et al., 2013; de Vries et al., 2013; Lange et al., 2015; Philippot et al., 2013; Wagg et al., 2014). Conventional intensive agriculture is a major pressure on these soil biodiversity-function relationships and can lead to their degradation and loss (de Vries et al., 2013; IPBES, 2019; Tsiafouli et al., 2015) 
with major implications for soil ecosystems, crop production and ultimately human health (Bender et al., 2016; Wall et al., 2015). Retaining both aboveand below-ground biodiversity, particularly of functionally complementary species, in a farm system or agricultural landscape provides direct and indirect benefits to crop production.

It is well known that the presence of natural areas or landscape heterogeneity is fundamental to supporting species diversity delivering ecosystem services in agricultural landscapes (Landis, 2017) and that habitat and landscape simplification under agricultural expansion erode this diversity and functionality (Fig. 3) (Dainese et al., 2019; IPBES, 2019; Newbold et al., 2016; Potts et al., 2016). For example, up to $50 \%$ of the negative effects of landscape simplification on ecosystem services is due to species richness losses of service-providing organisms. This includes negative consequences on crop yields (Dainese et al., 2019) and pollination and pest control by insects declines at increasing distances from non-cropped areas (Garibaldi et al., 2011; Woodcock et al., 2016). Increased land cover heterogeneity at field, farm or landscape scales can lead to increases in pollinator and natural enemy abundance as well as pollination and pest regulation (Batáry et al., 2011; Hass et al., 2018; Klein et al., 2012; Ricketts et al., 2008; Rundlöf et al., 2008; Rusch et al., 2016) (Fig. 3). These benefits are not universal, however, and the responses of pests and enemies to land cover often vary among organisms, across geographic regions, and between landscape and field management contexts (Gagic et al., 2017; Gallé et al., 2019; Karp et al., 2018). In a global synthesis of natural biocontrol, the landscape composition (\% non-crop habitat) was a significant predictor of pest and enemy abundance, predation rate, crop damage and yields, but positive and negative responses were observed across studies with no consistent overall trend (Karp et al., 2018). Therefore, as non-crop habitat does not always enhance biological control or other ecosystem services linked to biodiversity, more information about its modulation by agricultural contexts (see chapter "Landscape-scale expansion of agroecology to enhance natural pest control: A systematic review" by Petit et al., this volume) is needed to understand the reliability of habitat conservation as a pest-suppression strategy.

The configuration and arrangement of non-cropped areas in the landscape is now emerging as the potential key to effectively managing land to maintain natural biocontrol and pollination in agricultural landscapes. Complex landscapes with smaller and/or irregularly shaped fields and habitat patches have a high density of habitat edges. Such configurations of ecotones increase the probability of exchange of populations and ecosystem services 
between crop fields and non-crop habitat (Fig. 3). For example, a landscapescale analysis of wild bees and butterflies in Europe showed that pollinator assemblage evenness was greater in smaller and more connected habitat fragments, a consequence of community domination by generalist species with high dispersal capacity (Marini et al., 2014). In arable-dominated landscapes with high edge densities, $70 \%$ of pollinator and $44 \%$ of natural enemy species attained their greatest abundance, pollination and biocontrol improved 1.7and 1.4-fold, and achieved greater yields (Martin et al., 2019). Others have similarly shown how smaller field size and increased field border densities can elevate species abundances and pollination and pest regulation services (Dainese et al., 2017; Garratt et al., 2017; Hass et al., 2018). Furthermore, heterogeneous arable landscapes that contain large amounts of high quality field margin habitats providing floral resources can lead to increased levels of reproduction and population size of bumble bees (Carvell et al., 2017). In contrast, another large study found little evidence of landscape configuration influencing bee species richness and abundance, apart from a negative relationship to social bee abundance (Kennedy et al., 2013). Nonetheless, enhancing edge density in agricultural landscapes has the potential to promote functional biodiversity and ecosystem services that enhance yields (Fig. 3). The effects, however, will depend on the interaction of landscape structure with the response traits of the service-providing organisms. For example, Martin et al., 2019 found that ground-dispersing generalist natural enemies and pollinators whose larvae feed on crops or pests, were most abundant in arable-dominated landscapes with few edges, presumably because they are well adapted to exploit agricultural resources. Other pollinators and natural enemies that can fly benefit from high edge densities and interfaces with semi-natural habitats at landscape scales and so a high density of ecotones may be required for effective spillover of pollination or biocontrol services to the cropped area (Martin et al., 2019).

The management of agricultural fields is an important driver determining the availability and capacity of functionally important taxa to deliver ecosystem services. Soil organisms with their low capacity for active dispersal are primarily influenced and operate at more localized spatial scales (Veen et al., 2019), although patterns in land-use and non-cropped areas can sort and structure soil communities over time at the landscape scale (Eggleton et al., 2005; Vanbergen et al., 2007). Below-ground biodiversity is therefore mostly driven by field scale management practices such as tillage practices and agrichemical applications, so longer-term management to mitigate the negative effects of these practices can deliver benefits to below-ground 
biodiversity (Bender et al., 2016; Lal, 2006; McDaniel et al., 2014). More mobile pollinators and natural enemies and the services they provide are also consistently affected by in-field management, often in combination with the effects of landscape context (above and see chapter "Landscape-scale expansion of agroecology to enhance natural pest control: A systematic review" by Petit et al., this volume). Agricultural practices such as effects of fertiliser application, independent of pollinator availability in the area, have been shown to affect the extent that functionally important taxa contribute to crop output (Garratt et al., 2018a; Tamburini et al., 2019). Rusch et al. (2016) showed how combined management of semi-natural habitat and crop rotation can stabilize and enhance natural pest control in agricultural landscapes. Natural pest control of aphids in cereal crops was maximized in complex landscapes with monotonous and short crop rotations and minimized in simple landscapes with more diverse crop rotations that include perennial crops (Rusch et al., 2013, 2016). In a large-scale study in European arable systems, enhancing natural enemies and pest control by increasing landscape complexity proved to be disappointing in intensively cropped fields with denuded soil conditions (Gagic et al., 2017). Moreover, despite the evidence that organic agriculture (Section 4.2.2) can elevate pollinator and natural enemy abundance and diversity (Garratt et al., 2011; Katayama et al., 2019; Krauss et al., 2011), such benefits are not ubiquitous and often depend on landscape context, the spatial scale of assessment and the organisms concerned (Brittain et al., 2010; Schneider et al., 2014; Tuck et al., 2014; chapter "Landscape-scale expansion of agroecology to enhance natural pest control: A systematic review" by Petit et al., this volume).

In summary, agriculture has effects that operate from field to landscape scales, which impact and modulate biodiversity and functionally important taxa delivering ecosystem services in support of crop yields and ultimately human well-being (Fig. 3). Agriculture is therefore a major cause of biodiversity loss and ecosystem degradation, but it also presents potential solutions to these challenges to aid the transition towards sustainable development (Fig. 4).

\section{Alternative management approaches to conventional intensive agriculture}

The impacts of agriculture as a historical and current global driver directly shaping the climate, biodiversity, landscapes and ecosystem 


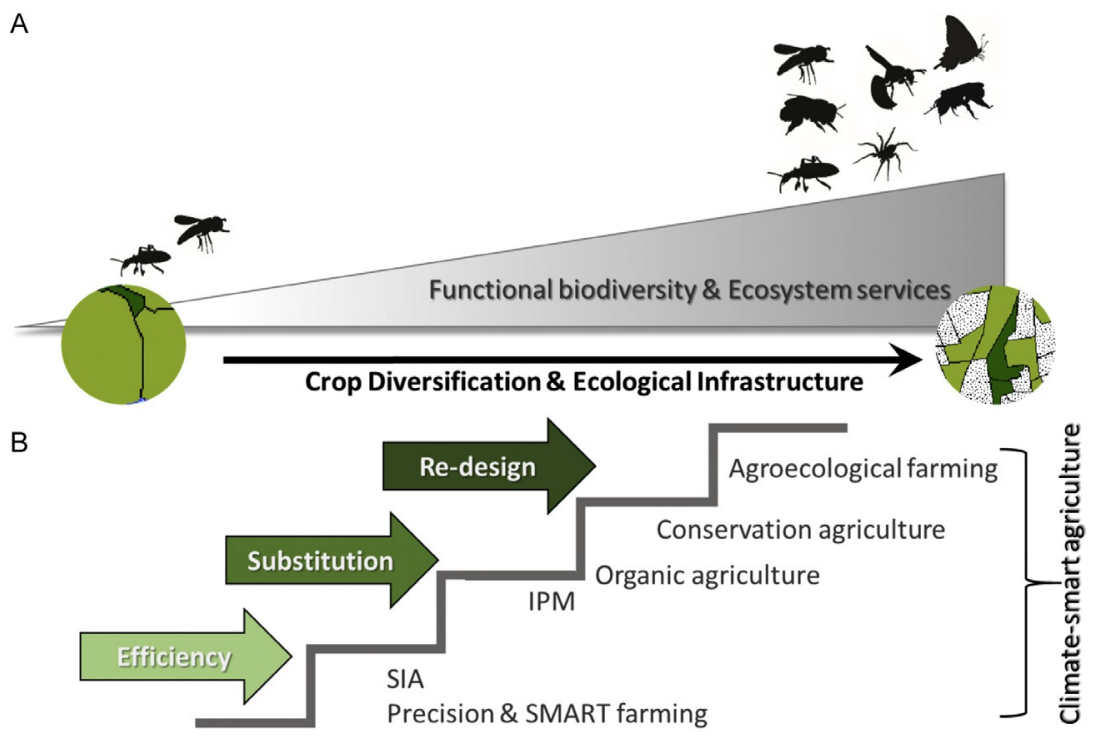

\section{Conventional Intensification}

Ecological Intensification

Fig. 4 The relationship between (A) functional biodiversity delivering ecosystem services (e.g. pollination, natural biocontrol) in support of crop yields along a gradient of crop diversification and ecological infrastructure and (B) alternative options (efficiency, substitution, redesign) for farm management systems situated on a continuum from conventional agricultural intensification to ecological intensification. Images sourced from shutterstock.com (free trial).

functioning are well understood (IPBES, 2019; IPCC, 2019). Although long acknowledged, the need to move towards more sustainable forms of agriculture has become critical with the ongoing ecosystem change and degradation as the 21 st century progresses. One solution involves transformative changes in society at all levels of governance, policy and practice to mitigate and reverse the adverse environmental impacts of human activities, including the current paradigm of conventional agricultural intensification, while maximising environmental resilience and food security (IPBES, 2019; Rockstrom et al., 2017). The precise forms that this future agriculture should take remains, however, hotly debated.

Currently, there are several alternative agricultural systems to conventional intensification (Fig. 4, Table 1). These vary in the role that technologies, management, external inputs or natural processes are used to support future agricultural production and in the socio-economic context determining the development and functioning of the farming system (Therond et al., 2017). 
Table 1 Summary of properties of farm management systems along the continuum of efficiency-substitution-redesign.

\begin{tabular}{|c|c|c|c|c|c|c|c|c|c|c|}
\hline & \multirow{2}{*}{$\begin{array}{l}\text { Goal } \\
\text { Farming system }\end{array}$} & \multicolumn{2}{|c|}{ Efficiency } & \multicolumn{2}{|c|}{ Substitution } & \multicolumn{5}{|c|}{ Redesign } \\
\hline & & $\mathrm{CIA}$ & SIA & IPM & OF & CA & DF & AF & EIA & CSA \\
\hline \multirow{12}{*}{ 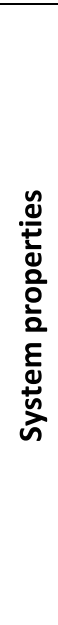 } & $\begin{array}{l}\text { Use of synthetic } \\
\text { inputs }\end{array}$ & $\checkmark \checkmark \checkmark$ & $\checkmark \checkmark \checkmark$ & $\checkmark \checkmark$ & $x^{2}$ & $x \sqrt{ }$ & $x^{2}$ & $x^{2}$ & $x \sqrt{ }$ & $\checkmark$ \\
\hline & Use of GMOs & $\checkmark \checkmark$ & $\checkmark$ & $x \sqrt{ }$ & $x \times x$ & $x \sqrt{x}$ & $\frac{x}{x}$ & $x \times x$ & $x^{2}$ & $\checkmark$ \\
\hline & $\begin{array}{l}\text { Encourage non- } \\
\text { farmed biodiversity }\end{array}$ & $x \sqrt{ }$ & $x^{2}$ & $\checkmark \checkmark$ & $\checkmark$ & $\checkmark \checkmark$ & $\checkmark \checkmark \checkmark$ & $\checkmark \checkmark \checkmark$ & $\checkmark \checkmark \checkmark$ & $\checkmark \checkmark \checkmark$ \\
\hline & High labour & $x \checkmark \checkmark$ & $\checkmark$ & $\checkmark \checkmark \checkmark$ & $\checkmark$ & $\checkmark \checkmark$ & $\checkmark \checkmark \checkmark$ & $\checkmark \checkmark \checkmark$ & $\checkmark \checkmark \checkmark$ & $\checkmark \checkmark \checkmark$ \\
\hline & Livestock integration & $x \sqrt{2}$ & $x \sqrt{ }$ & $x \times x$ & $\checkmark \checkmark$ & $x \sqrt{ }$ & $\checkmark \checkmark \checkmark$ & $\checkmark \checkmark$ & $\checkmark$ & $\checkmark \checkmark \checkmark$ \\
\hline & $\begin{array}{l}\text { Encourages spatial } \\
\text { heterogeneity }\end{array}$ & $x \checkmark \checkmark$ & $\checkmark$ & $\checkmark \checkmark$ & $\checkmark$ & $\checkmark \checkmark$ & $\checkmark \checkmark \checkmark$ & $\checkmark \checkmark \checkmark$ & $\checkmark \checkmark \checkmark$ & $\checkmark \checkmark \checkmark$ \\
\hline & $\begin{array}{l}\text { Uses nature-based } \\
\text { solutions }\end{array}$ & $x \sqrt{ }$ & $\checkmark$ & $\checkmark \checkmark$ & $\checkmark \checkmark$ & $\checkmark \checkmark$ & $\checkmark \checkmark \checkmark$ & $\checkmark \checkmark \checkmark$ & $\checkmark \checkmark \checkmark$ & $\checkmark \checkmark \checkmark$ \\
\hline & $\begin{array}{l}\text { Exploits ecological } \\
\text { processes up to } \\
\text { landscape scales }\end{array}$ & $x^{2}$ & $x^{2}$ & $\checkmark$ & $x \sqrt{ }$ & $\checkmark$ & $\checkmark \checkmark$ & $\checkmark \checkmark$ & $\checkmark \checkmark \checkmark$ & $\checkmark \checkmark \checkmark$ \\
\hline & Aims for resilience & $x^{x}$ & $\checkmark$ & $x^{2}$ & $\checkmark$ & $\checkmark \checkmark$ & $\checkmark \checkmark \checkmark$ & $\checkmark \checkmark \checkmark$ & $\checkmark \checkmark \checkmark$ & $\checkmark \checkmark \checkmark$ \\
\hline & Knowledge intensive & $x \sqrt{ }$ & $x \checkmark \checkmark$ & $\checkmark \checkmark \checkmark$ & $\checkmark$ & $\checkmark \checkmark$ & $\checkmark \checkmark \checkmark$ & $\checkmark \checkmark \checkmark$ & $\checkmark \checkmark \checkmark$ & $\checkmark \checkmark \checkmark$ \\
\hline & Focus on ILK & $x^{2}$ & $x^{2}$ & $x x x$ & $\checkmark$ & $\checkmark$ & $\sqrt{ } \sqrt{ }$ & $\checkmark \sqrt{ }$ & $\checkmark$ & $\checkmark \checkmark \checkmark$ \\
\hline & $\begin{array}{l}\text { Climate change } \\
\text { mitigation/adaptation }\end{array}$ & $x \times x$ & $x^{2}$ & $x x x$ & $x \times x$ & $\checkmark$ & $x^{2}$ & $\checkmark \checkmark$ & $\checkmark$ & $\checkmark \checkmark \checkmark$ \\
\hline
\end{tabular}

\begin{tabular}{|l|l|}
\hline Never & $x \times x$ \\
\hline Rarely & $x \checkmark$ \\
\hline Rarely sometimes & $x \checkmark \checkmark$ \\
\hline Sometimes & $\checkmark$ \\
\hline Sometimes often & $\checkmark \checkmark$ \\
\hline Often & $\checkmark \checkmark \checkmark$ \\
\hline
\end{tabular}

CIA, conventional intensification of agriculture; SIA, sustainable intensification of agriculture; IPM, integrated pest management; OF, organic farming; CA, conservation agriculture; DF, diversified farming; AF, agroecological farming; EIA, ecological intensification; CSA, climate-smart agriculture.

Adapted from IPBES, 2016. The assessment report of the Intergovernmental Science-Policy Platform on Biodiversity and Ecosystem Services on pollinators, pollination and food production. S.G. Potts, V. L. Imperatriz-Fonseca, and H. T. Ngo, (Eds.), Secretariat of the Intergovernmental Science-Policy Platform on Biodiversity and Ecosystem Services, Bonn, Germany. 
Transition to each of these different modes of sustainable agriculture requires differing levels of adaptation of the farming management system. This ranges from optimising production and decreasing waste (Section 4.1), substituting external products or procedures with deleterious environmental effects with less harmful procedures or with natural ecosystem processes (Section 4.2), to a co-production of a new farming system based on knowledge about the ultimate causes of inefficiencies and impacts to maximise agricultural and environmental benefits (Section 4.3) (Hill and MacRae, 1996; Pretty, 2018; Wezel et al., 2014). While efficiency and substitution tend to be additive and incremental within current production systems, redesign aims to transform the farming system but presents greater agricultural, social and institutional challenges (Garibaldi et al., 2017; IPBES, 2019; Pretty, 2018; Therond et al., 2017; see chapter "Sustainable agriculture: Recognizing the potential of conflict as a positive driver for transformative change" by Skrimizea et al., this volume). Thus, there are multiple alternative models of agricultural production varying in their reliance on nature or technology and the degree to which land is 'shared or spared' (see chapter "Combining land-sparing and land-sharing in European landscapes" by Grass et al., in press). These fall along a continuum ranging from relatively minor adjustments of efficiency to a wholesale transformation of the farm management system, but it is important to highlight the considerable overlap between them as they are not mutually exclusive and there is potential for interoperability (Fig. 4, Table 1).

\subsection{Optimisation of production through increased efficiency}

\subsubsection{Sustainable intensification of agriculture}

Sustainable intensification of agriculture (see Glossary) remains conceptually close to the standard model of conventional intensive farm management by relying on agri-technological solutions that enable the inputs of agrichemicals to be optimised through greater precision of timing and targeting (Fig. 4, Table 1). Sustainable intensification was originally conceived as an approach to increasing crop yield whilst improving ecological and social conditions (Godfray et al., 2010; Pretty, 1997). It posited reliance on agroforestry, conservation agriculture and biocontrol to establish lowinput and resource-conserving systems that promoted favourable ecological interactions within the agroecosystem, rather than dependence on external inputs. This was found to improve yields and livelihoods in developing economies (Godfray et al., 2010; Pretty et al., 2006). However, the more recent conceptualisation of sustainable agricultural intensification has shifted 
the focus towards capital and external input intensive solutions by both public and private parties (Tittonell, 2014) in order to enhance resource use efficiencies (Fig. 4), such as irrigation or fertilizer applications via precision agriculture (Fig. 2E) or use of genetic modification technologies (Fig. 2C) (Section 5.2). Smart systems that integrate remote-sensing, geo-positioning, big data, machine learning, drones and robotics (Fig. 2E) to precisely monitor crop and livestock health and target interventions (e.g. pesticide applications) either already exist or are advanced development (Liakos et al., 2018; Partel et al., 2019; Pretty, 2018; Wolfert et al., 2017). Coupled machine learning and ecological network modelling may offer a way for the aligning ecosystem service management with smart crop management systems (Tixier et al., 2013). There is great potential in these technological solutions to assure yield and reduce environmental harms, but continued reliance on hightechnology underpinned by access to finance or data means that this approach may exclude a subset of farmers (Section 5.3).

This has led to criticism that this concept does not promote social equity (Garnett et al., 2013; Loos et al., 2014) and fails to go far enough by working within and with natural ecosystem limits and processes (Rockstrom et al., 2017). As currently framed, sustainable intensification seeks to reduce waste and environmental harm (e.g. by fine-tuning agrichemical delivery) and possibly include a level of input substitution or crop diversification, but without radically adapting the conventional mode of intensive agriculture towards a wholesale redesign of the production system (Lemaire et al., 2014; Lin, 2011; Pretty, 2018; Wolfert et al., 2017). Therefore, where sustainable intensification of agriculture (as currently framed) is practiced, future landscapes will likely be improved, but not radically transformed in terms of conservation, management and use of beneficial biodiversity and ecosystem services (Fig. 4, Table 1).

\subsection{Substitution of external inputs or environmentally harmful procedures}

\subsubsection{Integrated pest management}

Integrated pest management (IPM) is an approach that depends greatly on knowledge of pest biology and ecology to allow tactical decision making by farmers in order to optimize the control of pest organisms (pathogens, weeds, insects, vertebrates) in an ecologically and economically sound manner (Ehler, 2006; Kogan, 1998). In its most basic form, IPM (see Glossary) aims to reduce use of environmentally harmful pesticides by choosing less toxic products or substituting chemical control with natural biocontrol, with 
pesticides employed only once an economic threshold of pest damage has been passed (Fig. 4, Table 1) (Ehler, 2006; Kogan, 1998). A broader interpretation, necessary for delivering long-term pest regulation, sees IPM being employed as part of a redesign (Section 4.3) of the crop management system aimed proximately at lowering pest pressure, while reducing pesticide use and ultimately providing economic savings for the farmer and protecting both the environment and human health (Barzman et al., 2015; Colbach and Cordeau, 2018; Pretty, 2018). To reduce pesticide reliance and maintain crop productivity, IPM seeks to optimize the synergy between a diverse set of pest management tools (biological, chemical, cultural, and mechanical) coherently combined at the scale of the cropping system, its rotations and the technical operations associated with each crop (Barzman et al., 2015; Swanton and Stephan, 1991). IPM systems require profound knowledge of pest biology along with interactive effects among pest management tools so as to promote longer-term synergies that disrupt pest species' niches and prevent outbreaks of highly adapted pests (e.g. pesticide resistance/tolerance) (Barzman et al., 2015). A sustainable IPM strategy should therefore combine all available methods, including the judicious and targeted use of pesticides, to facilitate a reduction in pest pressure. There are, however, challenges facing the implementation of IPM. In comparison to use of chemical pesticides, IPM can be time-consuming and complicated because of the need to implement multiple, concurrent practices against all classes of pests (Table 1). Moreover it requires the monitoring of pest populations to assure the implementation of the IPM tactic at the right time and place. Agricultural consultants, with the requisite knowledge to provide farmers with independent advice on the best tactics to employ within an IPM framework are not readily available in all parts of the world (Ehler, 2006; Kleijn et al., 2019). Therefore, the effective use of IPM in support of sustainable agriculture will require considerable reform of agricultural systems (Section 4.3), knowledge exchange, and socio-cultural change.

\subsubsection{Organic agriculture}

Organic farming (see Glossary) emerged from the need for a holistic system for enhancing soil fertility, water storage, and the biological control of crop pests and diseases (FAO, 2016; Reganold and Wachter, 2016). This was traditionally associated with low-input, small-scale, diversified farms. More recently the certification of organic farming has prohibited the use of most synthetic inputs and GMOs while allowing organic fertilizers and pesticides (Gomiero et al., 2011; Reganold and Wachter, 2016). 
Consequently, many organic farms today practice input substitution (Fig. 4, Table 1) and resemble conventional farms in that they are often high input, large-scale, and sustain low crop and non-crop diversity, but differ in using permitted organic products instead of synthetic fertilizers and pesticides (Guthman, 2014; Kremen et al., 2012). Similarly, there are low-input conventional farms operating that may use some of the practices of organic agriculture but that are not certified as being managed 'organically'. Currently, organic agriculture includes a wide spectrum of farming styles (Fig. 4) from smallholders to intensively managed large-scale systems (Gallé et al., 2019).

Organic agriculture has the potential to mitigate adverse effects of intensive farming. Species richness, functional diversity and abundance of a widerange of taxa are often higher on organic than conventional farms (but see Brittain et al., 2010; Gallé et al., 2019; Gomiero et al., 2011; Hole et al., 2005; Holzschuh et al., 2008; Katayama et al., 2019; Krauss et al., 2011; Schneider et al., 2014; Wintermantel et al., 2019). Positive effects of organic agriculture on biodiversity vary among landscape and crop types, levels of crop diversification. They are also contingent on the spatial scale at which the impact is assessed and the identity of the organism and its capacity to tolerate, adapt or respond to the management (Brittain et al., 2010; Gallé et al., 2019; Kremen et al., 2012; Schneider et al., 2014; Tuck et al., 2014). There is often a difference in crop productivity per unit area between conventional intensive agriculture and organic farming, with the former typically being higher yielding (de Ponti et al., 2012; Gomiero et al., 2011; Reganold and Wachter, 2016; Schrama et al., 2018; Seufert et al., 2012). Maintaining yield under an organic system may thus lead to expansion of the cultivated land area, potentially risking further habitat loss (Seufert et al., 2012) (Sections 1 and 3). This productivity gap can be narrowed by farm management, such as adoption of a diverse farming system following the principles of ecological intensification (Section 4.3) to improve crop interactions and agroecological functions (Kremen and Miles, 2012; Ponisio et al., 2015; Seufert et al., 2012). Although conversion to organic farming can lead to an initial yield drop, there is evidence that it ultimately improves yield stability, albeit with some time lags (several years) and variation among crop types (Andersson et al., 2012; Bedoussac et al., 2015; Ponisio et al., 2015; Schrama et al., 2018; Seufert et al., 2012). Organic farming can bring financial premiums to the grower and improve environmental outcomes (Gomiero et al., 2011; Reganold and Wachter, 2016). To achieve a level of sustainable farm production over time requires organic farming approaches to move from input substitution towards a redesign of the farm 
system, including modified management (e.g. sowing rates, alternative crop varieties, mechanical weeding), crop diversification and use of nature-based solutions (Section 4.3) that assure beneficial biodiversity and ecosystem services (see Glossary) (Fig. 4).

\subsection{Farming system redesign and nature-based approaches 4.3.1 Ecological intensification}

Ecological intensification describes an overarching set of principles and approaches to take a more transformative and nature-based approach to agriculture (see Glossary), which distinguish it from the methods underpinning conventional or sustainable intensification. It aims to maintain or increase long-term agricultural productivity, while reducing reliance on synthetic inputs and the need for further land-use conversion, through effective management of nature's contribution to people (see Glossary) (Garibaldi et al., 2019). In common with sustainable intensification of agriculture, resource use efficiency is sought by more precise and reduced (potentially 'zero') use of synthetic inputs. However, the pre-eminent principle of ecological intensification is to confer greater resilience on the farm system by working with co-existing biota and ecological processes to optimise soil fertility, plant performance, crop pollination and natural defences against pests and diseases (Fig. 4, Table 1, Box 1) (Bender et al., 2016; Bommarco et al., 2013; Kovács-Hostyánszki et al., 2017). This breadth of naturebased objectives distinguishes ecological intensification from both IPM (Section 4.2.1) and organic farming (Section 4.2.2) as typically practiced to date. Accordingly, ecological intensification is knowledge-intensive requiring the active management of farmland (Box 2) to increase the intensity of the ecological processes through ecological replacement or enhancement to close yield gaps (Bommarco et al., 2013; Kleijn et al., 2019; Tittonell, 2014) and is applicable to both large-scale and small-scale (Section 5.3) farming systems (Garibaldi et al., 2016).

Despite technological improvements, the benefits of conventional agricultural intensification are limited by the availability of ecosystem services or trade-offs occurring as a result of landscape composition (Catarino et al., 2019; Deguines et al., 2014; Montoya et al., 2019). Assurance of crop yield can only be achieved in the longer term by a sustainable management of biodiversity and ecosystem services that accounts for landscape structure (Fig. 4). Practices commensurate with ecological intensification and assurance of ecosystem services include the (re)establishment of ecological infrastructures (e.g. hedgerows, floral or grass strips), preserving or creating 


\section{BOX 1 Biocontrol in tropical irrigated rice systems (based on} Settele and Settle, 2018)

Rice is an annual crop, although in many parts of the world it is continuously cultivated with a long history of cultivation resulting in well-established and co-developed social-ecological systems. Where rice is grown alongside non-crop vegetation, landscape effects are not among the main factors driving the population dynamics of rice pests and their natural enemies. For tropical irrigated rice in Indonesia, spatio-temporal patterns of planting and harvesting within and between seasons are critical to pest dynamics, natural enemies and yields (Settle et al., 1996). Extremely large, synchronously planted areas of rice resulted in fewer natural enemy species and delayed their arrival into the system compared to regions characterised by small-scale, temporally heterogeneous rice cultivation (Settle et al., 1996) (Fig. 5A). This 'patch dynamics' of the rice field aids generalist predators that regulate pests by being abundant early in the season and before the arrival of the pests (Settle et al., 1996). If generalist predators can persist or rapidly recolonize newly planted fields, they can attain levels of species richness and abundance early in the season by feeding on the abundant populations of detritus- and filter-eating arthropods characteristic of aquatic and semi-aquatic rice systems to produce a consistent and robust biocontrol over time. At the landscape level, the temporal and spatial heterogeneity of the rice crops rather than the surrounding vegetative diversity of non-crop plants was the most important habitat factor determining population dynamics between pests and natural enemies in irrigated rice. Other studies (Dominik et al., 2018) have also shown that asynchronous agriculture forms a mosaic of cultivated and temporarily unused fields that provide a continuous supply of spatio-temporal resources to predators and parasitoids and helping them avoid spatial and temporal bottlenecks (Schoenly et al., 2010).

\section{Heterogeneity of landscape and habitat quality}

Rice pests and natural enemies can simultaneously react strongly to the surrounding landscape. In a study of 28 sites in the Philippines (Dominik et al., 2018), although prey abundance was the main factor affecting natural enemies, agricultural landscape composition and configuration the affected natural enemy functional groups in the rice arthropod community. The abundance of parasitoids and the species richness of parasitoids and predators increased with the structural connectivity of rice communities, which has also been shown to be an important element in other studies (Horgan et al., 2017). Bunds (dykes of the land surrounding the fields) form an extensive network connecting the rice fields typically composed of sparse semi-natural vegetation that can provide alternative food resources or refuges for natural enemies (Way and Heong, 1994). Bunds may facilitate rice arthropod persistence and dispersal through the rice agroecosystem. For example, egg parasitoids, which cause high mortality of pests, are found in wild grasses on rice bunds (Yu et al., 1996) and spider species 


\section{BOX 1 Biocontrol in tropical irrigated rice systems (based on Settele and Settle, 2018)—cont'd}

common in bund vegetation are early colonizers of newly-established rice crops (Sigsgaard, 2000). Bunds are the subject of environmental education activities in Vietnam. The sowing or planting of flower strips on these bunds (Fig. 5B) promotes parasitoids, but is also important as a food source for honeybees. Since the latter are highly valued in rural communities, it is easier to convince farmers
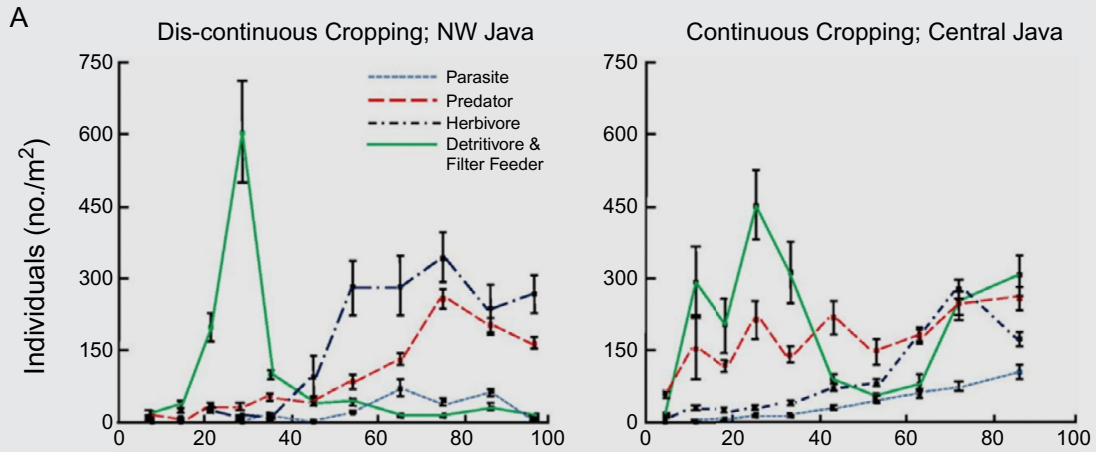

PNAS

No. of Days After Rice Transplanting

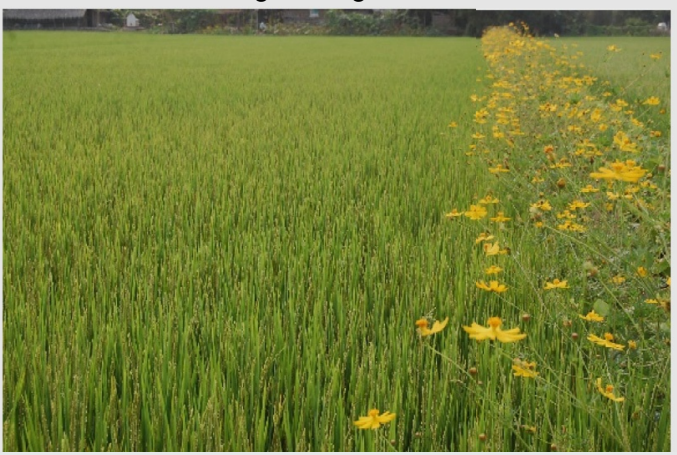

Fig. 5 (A) Dynamics of insect guilds in discontinuous (northwest Java; left graph) and continuous (central Java; right graph) systems during the first season. In rice landscapes characterised by synchronous and large-scale planting patterns and preceded by long, dry fallow periods, the arrival of natural enemies is severely delayed and herbivores reach much higher abundances (left graph). (B) Flower margin alongside a rice field. 


\section{BOX 1 Biocontrol in tropical irrigated rice systems (based on Settele and Settle, 2018)—cont'd}

not to spray insecticides, which reduces disruption of the ecological network within and along the rice fields. As an additional benefit, the landscapes are perceived as more beautiful. The involvement of farmers in these 'ecological engineering' activities increases the acceptance and effectiveness of landscapewide management of biocontrol and other ecosystem services (Westphal et al., 2015).

Since many species that inhabit rice paddies are specialized open grassland species, biodiversity in rice paddies in tropical Asia is often higher than in many natural ecosystems (Schoenly et al., 1998). It is therefore unsurprising that these species are more closely associated with the surrounding grasslands and nearby rice paddies at various stages of development than with other types of vegetation, e.g., agroforestry (Sann et al., 2018).

\section{Conclusions}

Eco-engineering of habitats in rice ecosystems has the potential to improve natural biological control of pests (Gurr et al., 2004; Horgan et al., 2016). Propagating flowering plants alongside rice fields to increase availability of food resources such as pollen, nectar and alternative hosts may improve natural enemy fecundity and longevity (Landis et al., 2000). The application of such ecological infrastructure has resulted in higher incidence of predators and parasitoids at agricultural sites in China, Thailand and Vietnam (Gurr et al., 2016).

natural or semi-natural habitats within and adjacent to farms and modifying management to include intercropping, reduced or no-till operations, or leaving a proportion of land fallow (Kovács-Hostyánszki et al., 2017; Potts et al., 2016). Such an ensemble of approaches can benefit plant microbiomes, soil decomposers, pollinators and natural enemies of pests that directly or indirectly support crop production (Bender et al., 2016; Bommarco et al., 2013; Kleijn et al., 2019; Kovács-Hostyánszki et al., 2017) (Box 1). Many of the practices under the umbrella of ecological intensification will contribute to mitigating the drivers of decline in pollinators and other biodiversity (IPBES, 2019; Kovács-Hostyánszki et al., 2017; Potts et al., 2016). Moreover, whilst currently evidence is currently limited, there are examples of enhanced crop pollination and yield assurance consistent with the application of ecological intensification (Blaauw and Isaacs, 2014; Feltham et al., 2015; Pywell et al., 2015). Knowledge gaps remain, however. The extent that ecological intensification can assure farm yields 
and profitability or those practices that are most effective for achieving the outcomes and when and where they should be employed, is not well understood.

Ecological intensification can also make other contributions to people, but these require participatory action, knowledge and training. Examples include improved human health from reduced pesticide use, increased production of nutritious food in areas with greater agricultural diversity (Herrero et al., 2017), and conservation of cultural heritages or traditions, such as the symbolic meaning and use of different species and the diverse landscapes preferred by people in which to live (Hill et al., 2019; Potts et al., 2016). As people hold different preferences or values, incorporating a variety of nature's contribution to people is necessary to produce an environment contributing to high value for all. Therefore, policies for land use should account for a plurality of views (legitimacy) and be relevant to the needs of people with different socio-economic characteristics (salience). In many respects, therefore, ecological intensification describes an ongoing process, an evolution rather than an endpoint and should be considered a necessary pathway to meeting the objectives of sustainable management, food security and resilience, and the broader goal of societal transformation (Garibaldi et al., 2017; IPBES, 2019; Rockstrom et al., 2017). Below we consider two specific farming approaches, conservation agriculture and agroecological farming, that we consider sit under the auspices of ecological intensification, but which vary in their breadth of nature-based solutions (see Glossary) and level of farm redesign.

\subsubsection{Conservation agriculture}

As a farming system, conservation agriculture (see Glossary) has a comparatively narrow focus on the management of soil and water resources in support of crop production, placing it at the frontier between substitution and nature-based approaches (Fig. 4, Table 1). Conservation agriculture requires substantial modifications to the type, timing, and rotations of crops with an emphasis on maintaining soil structure, beneficial soil biodiversity, water holding capacity and nutrient levels. It seeks to achieve this by minimising physical soil disturbance (i.e. zero tillage approaches) and agrichemical inputs, achieving a permanent soil cover using crop residues or living mulches to increase soil carbon and fertility, and employing diversification of plant species through crop rotations, use of cover crops, or intercropping (Giller et al., 2015). Through such actions, conservation agriculture aims to achieve enhanced beneficial biodiversity and natural ecological processes, 
above and below-ground, which contribute to increased water and nutrient use efficiencies and to improved and sustained crop production (Garratt et al., 2018b; Oldfield et al., 2019). However, it does not typically address other facets of agricultural management pertinent to ecological intensification such as natural biocontrol and crop pollination services.

\subsubsection{Agroecological farming}

A specific application of the concepts and principles of ecological intensification to the [re]design of the farm management system is agroecological farming (Wezel et al., 2014) (see Glossary). This aims to integrate environmental, sustainability and production goals by regenerating long-term agroecosystem properties through the incorporation of functional biodiversity (Tscharntke et al., 2012) (Box 1) alongside some technological or management innovations (Box 2) to produce a sustainable, resilient system (Altieri, 1999; Altieri et al., 2015; Wezel et al., 2014). Agroecological methods are knowledge, management, and labour intensive rather than external input intensive, and are often rooted in traditional farming practices or are co-developed by farmers and scientists with the aim to enhance food sovereignty (Altieri, 2004). A central tenet of agroecological farming is a move away from monocultures that dominate the conventional approach to agricultural intensification and towards the restoration or creation of a more complex and diversified agricultural system (Fig. 4, Box 2). For instance, it can be achieved through the employment of farming practices such as intercropping, permaculture, diverse crop rotations, conservation agriculture methods, agroforestry and integrated crop-livestock management (Brooker et al., 2015; Herrero et al., 2010; Iverson et al., 2014; Lemaire et al., 2014; Lin, 2011; Torralba et al., 2016). Integrating a diversity of crops and/or animals in the production system promotes agrobiodiversity across scales, regenerating or enhancing ecosystem services, and reducing the need for external inputs (Herrero et al., 2010; Kremen et al., 2012; Kremen and Miles, 2012; Malezieux et al., 2009; Rudel et al., 2016) (Table 1). Evidence suggests that diversified farming systems that integrate diversity of crops with livestock, agroforestry and ecological infrastructure can improve natural biological control (Iverson et al., 2014; Malezieux et al., 2009; Redlich et al., 2018) (Box 1) and pollination services (Hill et al., 2019; Potts et al., 2016), thereby contributing to yield production and stability.

To be attractive to farmers, agroecological farming (and other alternative approaches) need to be a viable economic option, either by demonstrating 


\section{BOX 2 The CA-SYS research platform: a co-designed agroecological system experiment (INRAE-Dijon, France)}

CA-SYS is an Agroecological System Experiments (ASE) located within the INRAE 'Domaine Epoisses' experimental unit. Its overarching objective is to design and test the feasibility and performances of pesticide-free agriculture using (cropped and wild) biodiversity in support of production, i.e., nature-based forms of agriculture (Cordeau et al., 2015). The CA-SYS platform is a farm scale experiment (125 ha, 42 plots) testing a diversity of zero-pesticide (excluding all synthetic and biopesticides including those authorized in organic agriculture) agroecological production systems (Fig. 6A).

\section{Cropping system experiment}

To address the challenges of transition to agroecological farming four pesticidefree cropping systems are being tested, following two agricultural pathways: (1) a tillage-based system (TS) inspired by organic agriculture (non-recurrent ploughing, false seedbed, mechanical weeding); (2) a no-till direct-sowing system (SD) maximizing soil cover and inspired by conservation agriculture. Both these options utilise a highly diverse crops rotations, both temporally (crop succession, Fig. $6 \mathrm{E}$ and F) and spatially (mixtures of species and/or varieties, Fig. 6D). A body of decision rules defining the cropping system, its objectives and constraints govern the management of each plot, and are adapted according the observed conditions of the plot (soil humidity, pest pressure, legacy of past crops, etc.).

\section{Landscape-scale approach for nature-based agricultural systems}

Agroecological systems require the coherent and strategic use of ecological infrastructure and ecosystem services from field to landscape scales. The CA-SYS experiment systemically incorporates a carefully designed spatio-temporal arrangement and management of fields with diverse cropping systems (Fig. 6E and F) along with semi-natural habitats at the level of a farm landscape (Fig. 6A and B). This ASE considers and tests the combined effects of land management options implemented at multiple embedded spatial scales. The scientific focus is therefore not limited to the temporal dimension of cropping systems, but also includes a spatial dimension that is highly relevant both ecologically (e.g. the issue of biological pest control) and agronomically, (i.e. how to organise a coherent farming strategy at the landscape scale). Non-cropped habitats cover 14.11 ha (i.e. 40.44 linear $\mathrm{km}$ of about $3 \mathrm{~m}$ wide habitats) and woodland and linear features (grass and wildflower strips, hedges, grassed paths or stony pathways bordered by vegetation). This ASE design thus employs a high coverage and diversity of habitats and plant composition over the farm and the opportunity to study the relations between agroecological cropping, landscape ecological infrastructure (a newly-established dense network of semi-natural field boundaries) and the dynamics of pests, natural enemies, pollinators and the resulting evolution of ecosystem services over the coming years. 


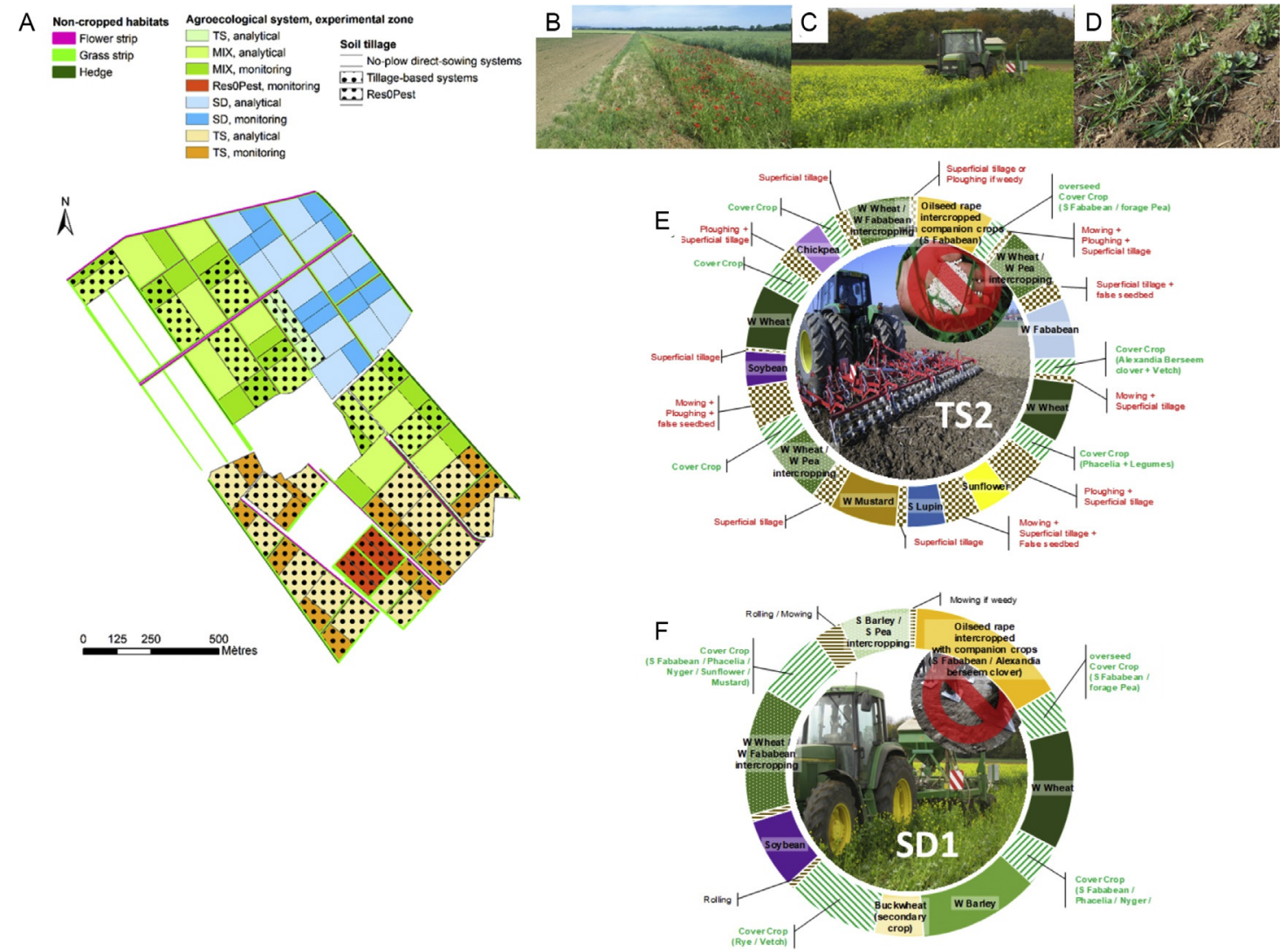

Fig. 6 (A) Map of the CA-SYS platform (Rodolphe Hugard and Violaine Deytieux (C) 2018), (B) 3-m wide flower strip bordered by two 3-m wide grass strips (Stéphane Cordeau @ 2019); (C) direct drilling in field conducted in Conservation Agriculture (Pascal Farcy @ 2018); (D) winter wheat intercropped with winter faba bean (Stéphane Cordeau (C) 2019); crop rotations initially designed for the permanent no-till system SD1 (E), rotational no-till system SD2 (not shown), tillage-based systems TS1 with (not shown) and without TS2 (F) N fertilisation. 
productivity broadly commensurate to that gained through conventional methods or by providing greater economic or environmental resilience or by attracting subsidies or finance for environmental outcomes (e.g. payment for ecosystem services or environmental goods). More research is needed to provide evidence on the level of yield and profitability that different ecological intensification approaches (agroecological farming, conservation agriculture) can attain relative to conventional intensification, particularly in different cropping or environmental contexts. Crucially these effect sizes, their context-dependency and the knowledge-intensive methods require close knowledge exchange and collaboration between scientists, agronomic advisors and farmers to ensure that new practices are applied in appropriate ways (where, when, how) that optimise production and environmental goals. This knowledge exchange, targeting and uptake represents a major hurdle for the transition from conventional intensive agriculture to new model agricultural systems. In many nations, there is a lack of independent agricultural advisors who can interpret the science and provide advice on the best application of novel practices for a specific context.

\subsubsection{Climate-smart agriculture}

Agriculture is the major factor contributing to climate change through habitat conversion, conventional management practices, livestock emissions, and use of energy by industrial machinery, transport and production of agrichemicals (IPBES, 2019; IPCC, 2019). Earth-system feedbacks mean that future agricultural production and food security will be jeopardised by climate change and its effects on the frequency and severity of extreme weather events and biodiversity loss (IPBES, 2019; IPCC, 2019; Lobell et al., 2011; Potts et al., 2016; Steffen et al., 2018). Future agricultural expansion and conventional intensification will only further increase greenhouse gas (GHG) emissions exacerbating climate change and eliminating or degrading natural biodiversity and ecosystem functions that confer Earth-system resilience (IPBES, 2019; Steffen et al., 2018). Increased climate variability is therefore a global threat to ecosystem function, agricultural productivity, livelihoods of farmers and rural communities and national economies, although the extent of these impacts is projected to vary considerably among world regions and economies (Garnett et al., 2013; IPBES, 2019; IPCC, 2019). Addressing the impact of climate change in concert with the effects of other direct and indirect drivers of global change is extremely complex and requires accounting for socio-economic conditions and environmental and temporal variations at all scales (IPBES, 2019; Vermeulen et al., 2013). 
Climate-smart agriculture (CSA) aims to moderate the impact of climate change on food production (see Glossary). CSA integrates economic, social and environmental aspects of sustainable development in a framework to achieve both food security and a mitigation and adaptation to climate change effects. It provides technical, political and investment solutions supported on three pillars: (1) sustainably increasing agricultural productivity and incomes; (2) adapting and building resilience to climate change; and (3) reducing and/or removing GHG emissions. The CSA approach is particularly focussed on developing economies (e.g. in sub-Saharan Africa and south Asia) striving to meet the interlinked challenges to food and nutritional security from yield gaps and increasing per capita consumption rates, environmental degradation, and extreme climatic events (Section 5.3) (IPBES, 2019; Wheeler and von Braun, 2013; Zougmore et al., 2018).

The CSA approach promotes the joint use of existing agricultural systems and practices known to benefit productivity alongside maximising nature's contributions to securing yields (Sections 4.2 and 4.3) to realise synergistic benefits for climate change adaptation and mitigation (Fig. 4, Table 1). Current and future options (Fig. 4) deployable as part of redesigning management for a climate-smart agriculture include the use of integrated crop and agroforestry systems (Section 4.3.1.2), IPM (Section 4.2.1), conservation agriculture (Section 4.3.1.1), and new highly efficient crop or forage varieties that reduce GHG emissions (Section 5.2) or under-utilised, orphan crops (Section 5.3) able to tolerate environmental extremes. For example, in comparison to conventional management regimes, integrating beef production with soybean rotations produced higher food production and lower GHG emissions per unit of human digestible protein, as well as increased financial and production resilience to future climate change (Gil et al., 2018). Climatesmart villages (CSV) or communities is a concept that works in conjunction with the principles and practice of agroecological farming (Section 4.3.1.2) to produce a socially-just system that brings potential benefits and resilience to food production, environment and climate change (Aggarwal et al., 2018; Altieri et al., 2015). Key to CSV is a multi-stakeholder, participatory approach integrating natural, technological, management and institutional knowledge contributing to the productivity and vulnerability of the system within a theory of change (Aggarwal et al., 2018). There is great potential therefore for CSA to draw upon the suite of options available under the auspices of sustainable and ecological intensification (Fig. 4, Table 1) to develop farm management systems that deliver to the objectives of climate resilience, food security and environmental sustainability in ways tailored to the specific context of different regions and peoples. 
A major barrier to the implementation of CSA approaches are mismatches between existing policies and climate-smart agricultural objectives including the implementation of technological innovation (Long et al., 2016). Four key areas for improvement have been identified to facilitate the implementation of CSA actions across all levels of decision making: (1) building evidence and assessment tools and providing access for everyone to this information; (2) strengthening national and local institutions including mainstreaming knowledge and practices across scales and sectors; (3) developing aligned and evidence-based policies for climate change and agriculture; and, (4) increasing financing and its effectiveness whilst reducing/eliminating perverse incentives (Aggarwal et al., 2018; IPBES, 2019; IPCC, 2019).

\section{Key issues affecting the transition to sustainable agricultural landscapes}

Global crises such as climate change, biodiversity extinction, environmental degradation and increasing inequalities have given rise to a growing criticism of the capacity of the prevailing agricultural and food systems to support sustainable development from the local to the global level and to a diverse call for sustainable transformations of these systems (Caron et al., 2018; IPBES, 2019; UN, 2015). However, the particular trajectory and possible form (Fig. 2B-E) of future sustainable agriculture(s) will be greatly affected by the outcome of social dynamics (Section 5.1) and broad societal trends, e.g., urbanisation (Section 5.1.1); the relative potential for emerging technologies (Section 5.2) and nature-based solutions (Section 4.3.1) to secure yields and minimise environmental harms; and the ecological state of land and the economic scale at which the farming system operates (Section 5.3).

\subsection{Social dimensions at the centre of agricultural transformations}

Implicit in the nascent agricultural reformation is the need for fundamental changes to the socio-technical-ecological architecture of agricultural and food systems, including shifts in underlying norms, values and power structures, and the introduction of new institutional structures (IPBES, 2019; Patterson et al., 2017; Pelling et al., 2015). This refocus on social rather than (solely) agronomic or technological change, along with the recognition of social justice and environmental integrity as the normative goals of 
transformations in agricultural and food systems will be crucial issues affecting future agricultural landscapes (Fig. 2F).

In this sense, the alternative farming approaches discussed above (Section 4, Fig. 4, Table 1) have to be considered alongside the social and political dimensions they entail and the support they receive from different societies or sections of society. Transformations to sustainable agricultural landscapes will therefore depend on farmer's opportunities (access), challenges and choices (Section 2), and will involve trade-offs and possibly conflicts among societal actors, e.g., urban dwellers, authorities or other rural habitants (see below). Furthermore, the transformation of the agricultural system will not only lead to modifications of the ecological landscape (Fig. 2G), but will also address issues of social justice and equitability between producers, workers and consumers (Feola, 2015). For instance, agroecology in Mexico is already expanding as a social and political movement led by indigenous and peasant communities resisting the model of conventional (industrial) intensive agriculture and aiming at food sovereignty (Toledo and Barrera-Bassols, 2017). There is therefore a need to address the deeper roots of the sustainability issues such as the drivers of poverty, access to decision making, social and economic context, vulnerability to climate change, etc. (Chandra et al., 2017). More research is needed to understand the importance of individual motivations and market incentives when facing changes and asymmetries in power dynamics at different scales (Dentoni et al., 2017). Nevertheless, considering the social dimension of agricultural transformation (Fig. $2 \mathrm{~F}$ ) will be central to avoid inducing unexpected or perverse outcomes in the structure, governance and sustainability of future landscapes.

\subsubsection{Urbanisation-A major societal trend affecting the future of agriculture and landscapes}

An important global societal trend is the increasing urbanisation of people and landscapes, which presents multifaceted risks and opportunities for sustainable agriculture and ecosystem health. This will requires decisions to be made about which alternative mode of agriculture can be adopted, where food production should be located with respect to population centres, and ultimately the values that societies place on foods, biodiversity and ecosystem functions, goods and services (Fig. 2).

Urban agriculture is one option to address the multiple challenges of feeding people and reducing environmental harms (Fig. 2B). Zero-acreage 'Zfarming' approaches advocate the production of certain foods inside the 
urban or peri-urban zone, either on or inside built structures under ambient or controlled conditions. By placing food production within the urban zone, Zfarming has the potential to lower agriculture's climate and environmental footprint, through closed circular systems and reduced transport, while reconnecting urban people with food production and generating other social benefits (Horst et al., 2017; IPBES, 2019; Orsini et al., 2013; Specht et al., 2014; Thomaier et al., 2015; Zasada, 2011). However, Zfarming may be limited to certain types of crop or farming approaches, encompassing a spectrum of management intensities ranging from extensively-managed allotments or home gardens to highly-intensive production under controlled glasshouse environments. It will therefore require careful planning and consideration of environmental and social limits and outcomes, including accessibility and social justice (Fig. 2F) (Horst et al., 2017; IPBES, 2019; Orsini et al., 2013).

A current feature of urbanisation and its distancing of the human population from the process of food production are growing shifts in the lifestyle, dietary expectations and choices of the increasing urban population. In many world regions, cultures and societal groups, urbanisation has been linked to greater economic affluence and a corresponding increase in consumption, including demand for meat (IPBES, 2019; IPCC, 2019). There is, however, a growing societal debate over modifying human diets and choices (meat consumption, flexitarianism, vegetarianism and veganism) with much of the debate focussed on the potential benefits of reduced or zero meat-based diet for the environment, animal rights and human health (IPBES, 2019; O'Keefe et al., 2016; Springmann et al., 2018; Willett et al., 2019). Should this shift away from high meat-based diets, perhaps allied to the development of alternative protein-rich foods (Section 5.2) (Fig. 2C), continue and achieve widespread cultural acceptability then it will elicit substantial changes in land-use and landscape structure (Fig. 2G) with projected benefits for climate change adaptation and mitigation (IPCC, 2019). The consciousness of and demand for organic food, driven by rising public environmental awareness, affluence and the perception that it is premium product (Reganold and Wachter, 2016), may represent a model for marketing novel foods and those produced and branded using nature-based (Section 4.3.1) or climate-safe (Section 4.3.2) farming solutions (Figs 2D and 4).

Urbanisation is an engine of social and environmental changes. The global trend of migration to cities from rural land in pursuit of work (Rigg et al., 2016) can lead to the partial or total abandonment of farmed 
lands with complex consequences for people, biodiversity and ecosystems. In extensively-managed landscapes of high biodiversity and cultural value this can lead to profound changes in or losses of biodiversity postabandonment due to the ecological succession or a transition to other land uses (IPBES, 2019). Increased urbanisation and migration to cities in rapidly developing economies are exacerbating the gender-asymmetry in smallholder agriculture (Section 5.3) with women taking an ever more important role as a knowledge holder and decision-maker with respect to farming, income and expenditure as men often leave for urban work (Jost et al., 2016; Orsini et al., 2013; Zimmerer et al., 2015). The intensity of rural depopulation has diminished in other places. Neo-rural immigration from urban areas, motivated by economic considerations or the pursuit of another rhythm of life in a historical and aesthetically attractive landscape has altered the social fabric of rural areas (Hoggart and Paniagua, 2001).

The abandonment of farmland and change in social structure or attitudes, sometimes through neo-rural immigration, can be seen as an opportunity for biodiversity conservation through land sparing (see chapter "Combining land-sparing and land-sharing in European landscapes" by Grass et al., in press) for the restoration of biodiversity and good ecosystem functioning (Henle et al., 2008; Navarro and Pereira, 2012; Queiroz et al., 2014). It may, however, also increase the potential for conflict between societal groups with different values and worldviews (see chapter "Sustainable agriculture: Recognizing the potential of conflict as a positive driver for transformative change" by Skrimizea et al., this volume). For instance, neo-rural immigrants or conservation groups may bring new priorities for land-use focussed on nature protection and recreation that can conflict with the orientation and expectations of local actors' like farmers. Hotly debated is the potential for ecological restoration (of an ecosystem), reintroduction (of a species), and rewilding (of a managed area). These options, along with afforestation for silviculture, biodiversity gains, or climate change mitigation, have been identified as potentially beneficial processes and goals on abandoned or marginalised agricultural land (Corlett, 2016; IPBES, 2019; IPCC, 2019). Restoration, reintroductions and rewilding aim to meet international conservation objectives (e.g. Bern Convention and the Convention on Biological Diversity, EC Directive on the Conservation of Natural Habitat and of Wild Fauna and Flora). The objectives of local rural communities are sometimes overlooked, leading to potential conflicts between societal groups (Coz and Young, 2020; Lorimer et al., 2015; Nogués-Bravo et al., 2016; O'Rourke, 2014). Such conflicts have led to a recent emphasis 
on developing guidelines not only on the ecological viability and risks of such initiatives, but also on their social feasibility and impacts (Butler et al., 2019). Such potential for social conflicts highlight the importance of dialogue and consensus building to achieve understanding, coexistence and co-development (Fig. 2F) of new configurations of agricultural landscapes (Mann and Jeanneaux, 2009; Nohl, 2001; Redpath et al., 2015; von der Dunk et al., 2011).

Urbanisation is therefore an excellent example of a multifaceted social, economic, and demographic phenomena impacting agricultural landscapes. The social changes and rising awareness of environmental risks linked to urbanisation of the human population points to possible alignment of sustainable agriculture, conservation of biodiversity and ecosystem services and climate adaptation (Fig. 2).

\subsection{Emerging biotechnologies for crop breeding and novel foods}

Another component of the potential transformation of the food system with implications for the ways in which landscapes are formed and utilised by humans are novel emerging technologies (Fig. 2C). Conventional breeding and genetic modification of crop cultivars, a key pillar of the conventional intensification of agriculture since the 'green revolution' of the 1960s, continue to offer opportunities to enhance agricultural production through the production of improved varieties (Godfray et al., 2010). Conventional breeding of plant lineages with back-cross selection of plant progeny with desired traits over several generations continues, but the low genetic variability within cultivars after millennia of domestication and the stochastic and time-consuming (typically $8-10$ years) nature of the process means it often fails to meet the demand for new varieties (Chen et al., 2019; Ghogare et al., 2019). Transgenic modification involving the insertion of exogenous genes (e.g. bacterial plasmids) coding for a desired trait into the genome of the target cultivar to create a new phenotype expressing the trait (Chen et al., 2019) offers the potential to generate new crop varieties. For example, future genetic improvements to reduce the dependence of certain crops on animal pollination of fruit/seed set could offer the possibility of improving the quantity or quality of yields in light of pollinator declines (IPBES, 2016). Although genetically modified crops circumvent the saturation of genetic potential in highly-domesticated crop species and will continue to offer the prospect of cultivar improvements, their 
release to market is limited by long and costly regulatory processes and public concerns (Chen et al., 2019; Ghogare et al., 2019).

The most recent and now widely adopted approach to crop improvement is that of genome editing (e.g. CRISPR/Cas9 and variants). This latest genetic manipulation tool allows the precise and direct modification of a target endogenous gene(s) or regulatory processes or rearranging chromosomes in a crop genome. This approach can precisely knock-out gene and regulatory elements that confer negative, undesirable trait properties or restrict hybrid potential and knock-in, replace or stack genes to elevate the expression of a desirable characteristic (Altpeter et al., 2016; Chen et al., 2019; Ghogare et al., 2019). Such genome editing approaches have the potential to increase the quantity and quality of yields, improve innate resistance to biotic and abiotic stressors, and increase the production rate of desired hybrids (c.f. conventional and transgenic methods). Underpinned by gene editing technologies, the emerging field of synthetic biology (Chen et al., 2019; Zhu et al., 2010) may lead to crop improvements by re-engineering crop physiology through the insertion of artificial DNA sequences to create novel cell and organism functions. One prospect is increasing photosynthetic capacity by re-engineering enzyme pathways and chlorophyll antenna in photosystems and optimising plant architectural traits to achieve gains in carbon metabolism and lower photorespiration that lead to greater crop efficiency (Ort et al., 2015; Zhu et al., 2010). Another alternative is the chemical manipulation of plant signalling using biosynthetic molecular precursors to elicit physiological responses (e.g. resource allocation) that enhance crop yields and resilience to environmental stress (Griffiths et al., 2016). As transformed cultivars move out of the lab and prove themselves in field trials they may present further opportunities to enhance yields per unit area, avoid further agricultural expansion and possibly allow for continued cultivation of land despite environmental change and degradation.

Away from crop improvements, the pioneering technologies of synthetic biology, laboratory-grown meat alternatives produced from vegetable, invertebrate or fungal protein, and food product manufacturing with $3 \mathrm{D}$ bioprinting of proteins, may, individually or in combination, produce a viable alternative to livestock farming (Mattick et al., 2012; Mouat et al., 2019; Portanguen et al., 2019; Stephens, 2013). Should the drive towards synthetic or alternative 'meat' continue and become acceptable to consumers, considered to be more ethical and marketable and scale-up for industrial production (Mayhall, 2019; Portanguen et al., 2019) then, coupled with increasing 
urbanisation (Section 5.1.1), this raises the prospect of a high protein diet that can spare the land from raising livestock. Where livestock grazing is intensive or requires habitat conversion, such a technological shift may have potential benefits in reducing agricultural GHG emissions and providing an opportunity for the restoration of biodiversity and ecosystems in the future landscape (IPBES, 2019; IPCC, 2019).

\subsection{The economic scale and ecological state of the farming system}

Another aspect that will influence the trajectory towards greater sustainability of the agricultural system is the economic scale of the farming system and the ecological state of the landscape in which it is situated. Conventional agricultural intensification characterised by industrial-scale food production has spread worldwide and brought greater food security (Section 1). However, small-scale agriculture (farm holding $<2$ ha, family-centred, Fig. 7) remains globally significant (FAO, 2015; Garibaldi et al., 2016; Lowder et al., 2019; Rigg et al., 2016; Steward et al., 2014; Zimmerer et al., 2015) and includes culturally important crops and landscapes (Globally Important Agricultural Heritage Systems (GIAHS)-Hill et al., 2019; IPBES, 2019). Small-scale agriculture is practiced mostly in developing economies by an estimated $80 \%$ of the global rural population $(\sim 2.0-2.5$ billion people), representing $84 \%$ of the $>600$ million farms worldwide and producing an estimated $36 \%$ of the world's food from only $12 \%$ of the global agricultural land surface (Lowder et al., 2019). Other estimates suggest $>70 \%$ of calories in Latin America, sub-Saharan Africa and parts of Asia are produced by smallholder family farms (Samberg et al., 2016). Consequently, small-scale agriculture is crucial to achieving food security (Lowder et al., 2019; Pretty et al., 2011; Rigg et al., 2016; Samberg et al., 2016) and global policy targets for alleviating poverty, hunger and achieving sustainable agricultures (UN, 2015).

Moving to a sustainable agriculture requires the balancing production of food alongside environmental benefits (Section 4) by optimising current approaches (Section 4.1) with emerging technologies (Section 5.2) or substituting (Section 4.2) or redesigning (Section 4.3) farm practices through integration or reconstitution of ecological infrastructure and nature-based solutions. The feasibility of the different options will be dependent on the economic scale and resources along with the ecological starting point of the system. 

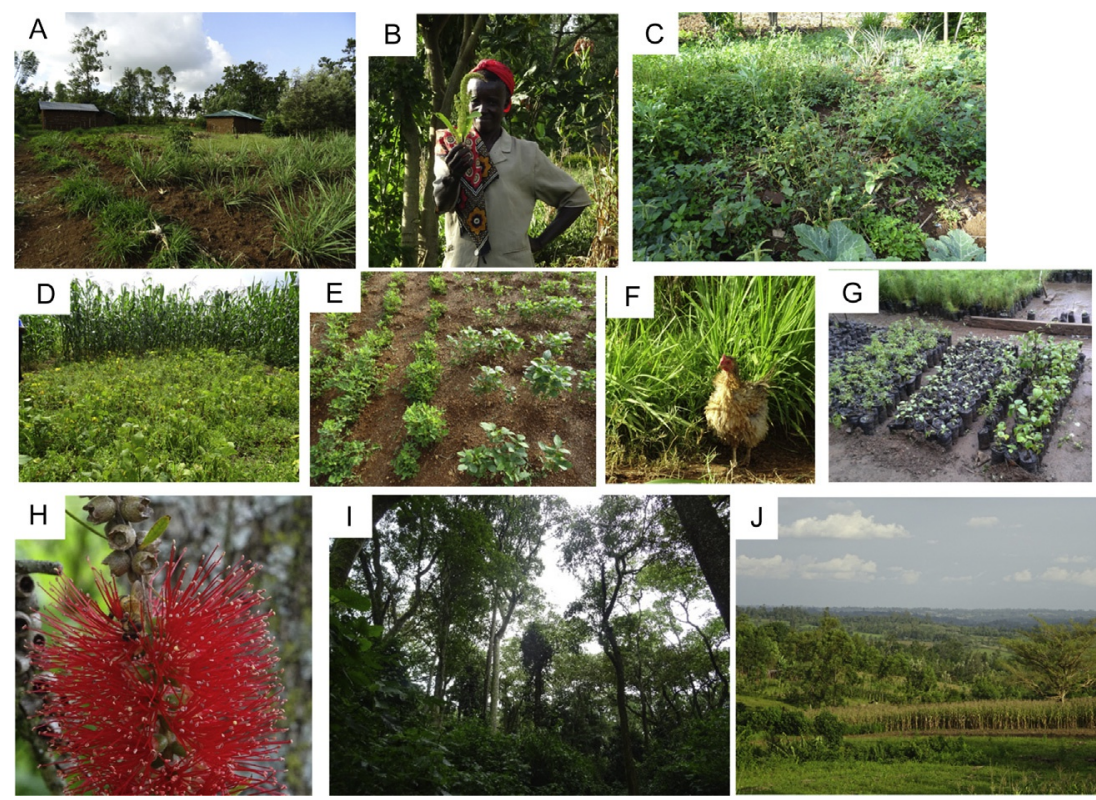

Fig. 7 Small-scale agriculture in East Africa (Kakamega, Kenya). Images of a typical (A) family-run smallholding where women (B) have a pivotal role as knowledge holders and in running households and farms. Subsistence foods and cash crops ( $C-E)$, livestock $(F)$ and agroforestry trees ( $G$ and $H$ ) that provide shade, animal fodder and timber are managed in polyculture. Agroforestry trees ( $G$ and $H)$ and natural forest reserves (I) provide ecosystem services (watersheds, pollinators, natural enemies) but also potential disservices (vertebrate pests, water competition between on-farm trees and crops). A patchwork of family ownership, polyculture, agroforestry and natural areas produce a highly diverse, but highly anthropogenic, landscape structure (J).

Many of the options are compatible with large and small-scale agriculture, but these smaller production systems also face a multiplicity of specific demographic, economic and environmental challenges. They tend to be situated in economies in the lower brackets of household income, with limited access to capital and technologies (Abdul-Salam and Phimister, 2017; FAO, 2015; Lowder et al., 2019; Rigg et al., 2016). Food insecurity is likely to grow because the forecasted growth in the global human population (Section 2) will mainly occur in the low to middle income economies where small-holder agriculture predominates. This is especially the case in Africa where the predicted doubling of the population by 2050 to 2 billion may produce a per capita decline in food production where $52.7 \%$ of people already experience moderate to severe food insecurity (FAOSTAT, 2017; Pretty, 2018; Pretty et al., 2011; Rigg et al., 2016; UN, 2019). Small-holder 
farmers in these developing economies also face persistent yield gaps and economic vulnerability (Fermont et al., 2009; Lowder et al., 2019; Tittonell and Giller, 2013; Waddington et al., 2010). This is due to biophysical constraints, lack of agronomic and agroecological advice, physical or financial infrastructure and economies of scale (Abdul-Salam and Phimister, 2017; Pretty et al., 2011; Rusere et al., 2019a; Tittonell and Giller, 2013; Zimmerer et al., 2015). Small-holder agricultural systems are also likely to be most affected by global climate change, either directly because developing world regions will be most affected by earth system impacts (e.g. increased drought, erratic precipitation) or indirectly because their economic scale means they lack adaptive capacity (Chaplin-Kramer et al., 2019; Godfray et al., 2010; IPBES, 2019; IPCC, 2019).

Achieving a sustainable small-scale agriculture and nutritional security will require solutions tailored to meeting these challenges and to their different socio-ecological history, land-use and landscape structure (Fig. 7) (Hill et al., 2019; Rusere et al., 2019a,b; Tittonell and Giller, 2013).

A feature of small-scale agriculture is that the people retain a closer, more direct link to food production than most people in highly developed economies where large-scale agriculture prevails. Smallholder farmers tend to be family-centred in terms of labour and reliance on the land for household revenue (although this may also be the case in large-scale agriculture). Importantly, their nutritional security, and that of the wider rural community, depend crucially on goods (crops, livestock, non-food products) produced, sold and consumed at the household level (Lowder et al., 2019) (Fig. 7). Improving financing opportunities, encouraging farmerled cooperatives for economies of scale and risk sharing, and promoting local-to-global value chains that account for social justice, equity and gender positions (Jost et al., 2016; Zimmerer et al., 2015) are vital to sustain or improve yields and mitigate environmental and economic risks for small-scale, but also large-scale, farm operations.

Efficiencies can be gained from leveraging access to improved crops, for both smallholder and large-scale farmers, produced through genome editing technologies (Section 5.2) (Fig. 2C) through national research and industrial infrastructure, financial instruments and cooperative purchasing. This includes the potential for the genetic improvement (Section 5.2) and polyculture of orphan, under-utilised crop and agroforestry species (Dawson et al., 2019; Rosenstock et al., 2019) possessing traits that confer greater economic and environmental resilience to farm yields. Most immediately, the use and improvement of digital, mobile SMART technologies and basic 
electronic infrastructure (Fig. 2E) can improve farm efficiencies and yields through better education, knowledge communication and mobile applications to promote good practice, innovations and avoid malpractices (AbdulSalam and Phimister, 2017).

Unlike most industrial-scale systems, small-scale farmers already tend to employ diversified approaches (Figs 4 and 7), including polyculture with minimal external inputs, combinations of cash and subsistence cropping, and integration of livestock and agroforestry (Hill et al., 2019; Pretty et al., 2011; Rosenstock et al., 2019). Consequently, landscapes dominated by small-scale agriculture tend to be considerably more heterogeneous with respect to habitats and the organisms (Figs 3 and 7) compared to large-scale systems transformed by conventional agricultural intensification (Section 3) and so may be on a potentially different trajectory.

Therefore, an opportunity exists to avoid environmental degradation by utilising the benefits of an already diversified landscape and pool of serviceproviding organisms to deliver nature-based solutions following the principles of ecological intensification (Fig. 2D) (Section 4.3) (Garibaldi et al., 2016, 2017; IPBES, 2019; Kovács-Hostyánszki et al., 2017; Rockstrom et al., 2017; Rusere et al., 2019a; Tittonell and Giller, 2013). Although there is some knowledge from temperate and intensively managed large-scale systems on the links between landscape heterogeneity, biodiversity, and ecosystem goods and services (Section 3) (Fig. 3), there is comparatively less evidence on the importance of beneficial agrobiodiversity in smallholder systems (Garibaldi et al., 2016; Steward et al., 2014). Therefore, further research is required to understand the applicability of transferring evidence from more intensively-managed agricultural landscapes to small-scale systems, and vice versa, and how diversified farming (livestock, traditional and cash crops, agroforestry) can be integrated with nature-based approaches to increase the amount and stability of yields (Garibaldi et al., 2017; Pretty, 2018; Pretty et al., 2011). Although also relevant to large-scale agricultural systems, the potential design of agroecological (Section 4.3.1.2) and diversified farming systems that contribute to the building of a climate-smart agriculture (Section 4.3.2) and resilient future food production is of particular importance to low-income smallholder communities with the greatest vulnerability to global environmental changes (Altieri et al., 2015; IPCC, 2019; Rosenstock et al., 2019).

Agenda 2030 of the United Nations (UN, 2015) states: '...by 2030, double the agricultural productivity and the incomes of small-scale food producers, particularly women, indigenous peoples, family farmers, pastoralists 
and fishers, including through secure and equal access to land, other productive resources and inputs, knowledge, financial services, markets and opportunities for value addition and non-farm employment (SDG2: Target Section 2.3)'. Integrating and targeting an ensemble of technological (Fig. 2C and E) and nature-based (Fig. 2D) approaches for conserving biodiversity and assuring farm productivity, drawing on the experience of smallscale and large-scale agricultural systems, will help to promote sustainable agriculture, improve food and nutritional security and minimise ecosystem risks (Section 3).

\section{Conclusions}

Conventional intensive agriculture through field management and its effects on landscape composition and structure is a major cause of biodiversity loss and ecosystem degradation, which profoundly modifies functional biodiversity delivering ecosystem services to crop yields and human wellbeing (Section 3). Agriculture also represents an interconnected and interlinked sector which can influence the transition towards sustainable development and mitigating global environmental change (Fig. 2). It is clear that the paradigm of conventional agricultural intensification requires reform to dramatically reduce its worst effects and maximise the potential benefits of reconsidering the spatio-temporal scale and diversity of farm management.

There exists a spectrum of alternative agricultural models, to an extent overlapping and interoperable, varying in their reliance on nature or technology and the level of transformative change required, ranging from adjustments to efficiency to a wholesale redesign of the farm management system (Section 4, Fig. 4, Table 1). To reverse the ecological degradation of agricultural lands seen worldwide and to shift it towards a sustainable system will require that nature-based approaches, like those under the umbrella of ecological intensification (Section 4.3), are placed at the core of future agricultural management, but also the entire food system and value chains. This does not preclude a role for novel technologies that help to optimise or facilitate increased production (Section 5.2), but future technologies must be applied alongside nature-based solutions in a systems approach and work within the limits of the ecological landscape. Moreover, it is important to emphasise that no one solution is universally applicable given the socio-economic and ecological heterogeneity worldwide, instead a future agricultural system should comprise a suite of options applied in the most efficient, but environmentally sustainable and resilient way for each context 
(Fig. 4, Table 1). We should draw upon the best features of small-scale, diversified agricultural systems (Section 5.3, Fig. 7), the positive effects of extensive ecological infrastructure (Sections 3 and 4.3.1, Fig. 3) and the potential of new technologies (Sections 4.1.1 and 5.2) to design future sustainable farm management systems that can be adjusted to the specific local context (Fig. 2).

This transformation of the agricultural system to meet the challenges of our time requires active research (Box 3 ) and stakeholder co-development

\section{BOX 3 Future research questions to address the transition to sustainable agricultures}

- What is the optimal scale (field to landscape) and quantity, quality, and configuration of habitats needed to deliver multifunctional biodiversity and ecosystem services that support agricultural yields?

- What level of farm complexity (crop rotations, ecological infrastructure) provides the requisite supply of ecosystem services to offset the reduction in external inputs and secure crop yields?

- At what level of landscape complexity do disservices (pests, pathogens) outweigh ecosystem services to crops?

- What conditions enable, and how long does it take, to transition to a naturebased farm management system that assures yields comparable to those under conventional intensive management?

- What combinations of field management practices and ecological infrastructure result in the greatest level of combined above and belowground ecosystem services to crops?

- How does the local context (environmental, socio-economic) affect the relative gains from approaches aimed at efficiency, substitution or redesign of the system?

- Does the scale of multiple benefits from nature-based solutions differ between large and small-scale agricultural systems?

- Does the success of small-scale management for enhancing ecosystem services depend on landscape context?

- Which crop types (conventional, bioengineered, traditional or orphan) perform best in diversified and/or nature-based farm management systems?

- What are the social, economic, cultural and institutional barriers to a sustainable agricultural transformation?

- Can conflicts between societal actors be used as a positive engine for dialogue, trust-building and consensus on a future agricultural and food system?

- What is the potential for synthetic or non-meat proteins to become economically scalable, culturally acceptable, and to spare land for other uses? 
over the coming decade to realise future sustainable farming approaches. While food production will remain key, diversification of farm practices in terms of crop rotations, integration of livestock and/or trees, and the creation of ecological infrastructure for ecosystem service delivery will combine to produce heterogeneous landscapes that deliver biodiversity restoration and multiple contributions to human well-being (Díaz et al., 2018) (Fig. 2). Social and demographic drivers such as those associated with urbanisation (Section 5.1.1) will also greatly influence the future landscape. Translocation of intensive food production to the urban zone, shifts in cultural attitudes or diets due to an urbanising population, or technological advances (e.g. meat-free protein, synthetic biology, 3D bioprinting) may create opportunities for changes to agricultural landscapes by switching to alternative land-uses delivering other environmental goods (timber, bioenergy, fibre) or ecosystem benefits (carbon sequestration, biodiversity restoration). Further complexity and potential constraints emerge from differing worldviews (and potential conflicts—see chapter "Sustainable agriculture: Recognizing the potential of conflict as a positive driver for transformative change" by Skrimizea et al., this volume) among societal groups about their relative roles and responsibilities, rights and social and cultural norms. Considering the social dimension is thus crucial to the success of agricultural transformation and the outcomes for food security and reversing the adverse human impacts on the environment (Section 5.1) (Fig. 2).

Shifting to an alternative agricultural paradigm, if done properly, will encompass multifunctional landscape planning and cross-sectoral integrated and participatory management. Therefore it will span multiple policy sectors, actors and knowledge holders requiring decision-making processes to become interoperable in an effective way to avoid unanticipated or perverse outcomes and inter-sectoral competition for finite land resources (IPBES, 2019) (Fig. 2). Science in conjunction with indigenous and local knowledge (ILK), must have an important role in this evidence-informed policy to guide decision making through the complexity and interconnectedness of the natural world and the agricultural and food system. Trans- or inter-disciplinary approaches integrating biological, social and economic sciences to understand better the merits of different modes of agriculture in assuring yields, nutritional security and social justice will be essential. Alternative modes of agricultural management can achieve high yields and profits (Reganold and Wachter, 2016), but evidence of the simultaneous impacts of farming systems on ecological, social, and economic aspects of sustainability are scarce (Garibaldi et al., 2017). The study of each aspect 
belongs to different research fields, each with its own idiosyncrasies and vocabulary. An increase in the number of studies that use a common framework to quantify these multifaceted impacts would facilitate the finding of high-level patterns to help understand what solutions are most likely to work in which situations, across regional and national lines, and across specific farming systems.

The current food system is seen as the driver of many negative impacts on the global environment by both key intergovernmental organisations (CBD, 2014; IPBES, 2019; IPCC, 2019) and the scientific community (Kovács-Hostyánszki et al., 2017; Newbold et al., 2016; Potts et al., 2016). Priorities need to be established for identifying farming systems that can generate benefits in multiple dimensions, whilst eliminating negative externalities and accepting solutions tailored to different environmental, political and social contexts (DeLonge et al., 2016; Kleijn et al., 2019) (Figs 2 and 4, Table 1). The scientific literature sometimes complicates the debate by failing to distinguish between the different objectives implied by concepts of agricultural production versus food production versus food security (Garibaldi et al., 2017). Moreover there is a mismatch between scientific understanding of alternative approaches such as ecological intensification and uptake by farmers (DeLonge et al., 2016; Kleijn et al., 2019). Space should be given to other knowledge holders and practitioners (e.g. farmers, agricultural extension services, business and industry, indigenous peoples) to engage with scientists to ensure that new agricultural systems emerge from a dialogue that helps to assure lessons are learned, conflicts avoided and multiple outcomes achieved. Moreover, sustained and radical political commitment at the highest levels (Pe'er et al., 2020) is needed to build upon intergovernmental agreements (CBD, 2014; IPBES, 2019; UN, 2015). New national and international policies, levers and incentives (e.g. payments for environmental goods and services; new certifications and labelling for quality control and consumer informed choices) (Pe'er et al., 2020) are required to deliver the interlinked goals of food and nutritional security, environmental restoration, poverty reduction and local development.

Agriculture relies on beneficial biodiversity and ecosystem processes, but it is also a socio-cultural and industrial practice driving major ecosystem degradation and biodiversity extinction. This means that agricultural reform is a necessity for a transition to sustainable food production, responding to global change and safeguarding food and nutritional security. There are a plethora of options to address the challenges of feeding a world with a growing 
population and per capita consumption pattern, in an equitable way, and assuring the restoration of biodiverse and resilient ecosystems. The ultimate key to the successful transformation of agriculture and the landscapes it supports are people and their capacity to accept new ways of living and working in response to the current environmental crisis.

\section{Glossary of terms}

Conventional intensive agriculture (CIA) Industrial-scale mechanized management of livestock and large-scale monocultures in simplified rotations of high-yielding varieties (including GM) that are heavily reliant on high levels of agrichemical inputs (fertilisers insecticides, herbicides, fungicides)

Sustainable intensification of agriculture (SIA) Originally defined as increasing crop yields while improving ecological and social conditions using sustainable practices (e.g. agroforestry, conservation agriculture, and IPM). Recent concept retains capital intensive and agri-technological approaches to CIA but enhancing efficiencies, and precisely timed and targeted inputs (irrigation, fertilizer, pesticides) to high-yielding crop varieties and avoiding/minimising environmental impacts

Ecological intensification of agriculture (EIA) A nature-based approach to agriculture aiming to maintain or increase long-term agricultural productivity, while reducing reliance on synthetic inputs and the need for land expansion, by managing landscapes and ecological processes (pollination, nutrient recycling, biocontrol) in support of production and thereby reducing environmental impact

Agroecological farming Under the banner of EIA. A knowledge, management, and labour-intensive approach aiming to produce a sustainable, resilient system using and restoring functional biodiversity and reducing need for external inputs, ultimately leading to a diverse farm. Methods often rooted in traditional farming practices and/or are co-developed by farmers and scientists, sometimes with the aim to enhance food sovereignty

Diversified farming system Allied with 'agroecological farming' and 'ecological intensification', but emphasizing integration of multiple crops and/or livestock across scales as the primary mechanism alongside promotion of agrobiodiversity and ecosystem services, and reduction of external inputs to achieve sustainable production

Conservation agriculture Managing the type, timing, and rotations of crops with an emphasis on maintaining and improving the structure, biodiversity, water holding capacity and nutrient levels of soils

Climate-smart agriculture (CSA) An integrated approach to managing landscapes of cropland, livestock, forests and fisheries to address food security and climate change. It aims to improve food and nutritional, reduce vulnerability to environmental shocks (e.g. extreme weather, pests, diseases), reduce GHG emissions and improve carbon sequestration

Integrated pest management Reducing use of environmentally harmful pesticides by choosing less toxic products or substituting chemical control with natural biocontrol, and maintain crop productivity through a diverse set of pest management tools (biological, chemical, cultural, and mechanical). Pesticides employed only once an economic threshold of pest damage has passed. Knowledge and monitoring intensive 
Organic farming Originally aiming to enhance soil fertility, water storage, and biocontrol of crop pests and diseases and often in small-scale diversified systems. Now includes a wide spectrum of farming options including large-scale intensive systems. Prohibits the use of most synthetic inputs and GMOs while allowing organic fertilizers and certified biopesticides

Ecological infrastructure Interconnected natural or semi-natural habitat patches or linear features that are maintained, restored or created in order to promote functional biodiversity, ecosystem functions and delivery of services across temporal and spatial scales

Nature-based solutions Actions inspired and supported by nature to protect, sustainably manage, and restore natural or modified ecosystems and functions, that address societal challenges and build resilience thereby simultaneously providing for human well-being and benefiting biodiversity

Ecosystem services The benefits people derive from ecosystems, including provisioning services or goods (e.g. food, wood, water), essential biodiversity-mediated regulating services (e.g. pollination of crops, prevention of soil erosion, water purification) and cultural services (e.g. recreation, a sense of place)

Natures contributions to people (NCP) All the positive contributions, or benefits, and occasionally negative contributions, losses or detriments, which people obtain from nature. Strongly linked to the term ecosystem services, but goes further including concepts associated with other human-nature relations and knowledge systems (e.g. 'nature's gifts' in many indigenous cultures)

\section{References}

Abdul-Salam, Y., Phimister, E., 2017. Efficiency effects of access to information on smallscale agriculture: empirical evidence from Uganda using stochastic Frontier and IRT models. J. Agric. Econ. 68, 494-517.

Aggarwal, P.K., Jarvis, A., Campbell, B.M., Zougmore, R.B., Khatri-Chhetri, A., Vermeulen, S.J., Loboguerrero, A.M., Sebastian, L.S., Kinyangi, J., Bonilla-Findji, O., Radeny, M., Recha, J., Martinez-Baron, D., Ramirez-Villegas, J., Huyer, S., Thornton, P., Wollenberg, E., Hansen, J., Alvarez-Toro, P., Aguilar-Ariza, A., Arango-Londono, D., Patino-Bravo, V., Rivera, O., Ouedraogo, M., Yen, B.T., 2018. The climate-smart village approach: framework of an integrative strategy for scaling up adaptation options in agriculture. Ecol. Soc. 23 (1), 14.

Aizen, M.A., Aguiar, S., Biesmeijer, J.C., Garibaldi, L.A., Inouye, D.W., Jung, C., Martins, D.J., Medel, R., Morales, C.L., Ngo, H., Pauw, A., Paxton, R.J., Sáez, A., Seymour, C.L., 2019. Global agricultural productivity is threatened by increasing pollinator dependence without a parallel increase in crop diversification. Glob. Chang. Biol. 25, 3516-3527.

Altieri, M.A., 1999. The ecological role of biodiversity in agroecosystems. In: Invertebrate Biodiversity as Bioindicators of Sustainable Landscapes. Elsevier.

Altieri, M.A., 2004. Linking ecologists and traditional farmers in the search for sustainable agriculture. Front. Ecol. Environ. 2, 35-42.

Altieri, M.A., Nicholls, C.I., Henao, A., Lana, M.A., 2015. Agroecology and the design of climate change-resilient farming systems. Agron. Sustain. Dev. 35, 869-890.

Altpeter, F., Springer, N.M., Bartley, L.E., Blechl, A.E., Brutnell, T.P., Citovsky, V., Conrad, L.J., Gelvin, S.B., Jackson, D.P., Kausch, A.P., Lemaux, P.G., Medford, J.I., Orozco-Cardenas, M.L., Tricoli, D.M., Van Eck, J., Voytas, D.F., Walbot, V., 
Wang, K., Zhang, Z.Y.J., Stewart, C.N., 2016. Advancing crop transformation in the era of genome editing. Plant Cell 28, 1510-1520.

Andersson, G.K.S., Rundlöf, M., Smith, H.G., 2012. Organic farming improves pollination success in strawberries. PLoS One 7, e31599.

Barzman, M., Bàrberi, P., Birch, A.N.E., Boonekamp, P., Dachbrodt-Saaydeh, S., Graf, B., Hommel, B., Jensen, J.E., Kiss, J., Kudsk, P., Lamichhane, J.R., Messéan, A., Moonen, A.-C., Ratnadass, A., Ricci, P., Sarah, J.-L., Sattin, M., 2015. Eight principles of integrated pest management. Agron. Sustain. Dev. 35, 1199-1215.

Batáry, P., Andras, B., Kleijn, D., Tscharntke, T., 2011. Landscape-moderated biodiversity effects of agri-environmental management: a meta-analysis. Proc. R. Soc. B Biol. Sci. 278, 1894-1902.

Bedoussac, L., Journet, E.P., Hauggaard-Nielsen, H., Naudin, C., Corre-Hellou, G., Jensen, E., Prieur, L., Justes, E., 2015. Ecological principles underlying the increase of productivity achieved by cereal-grain legume intercrops in organic farming. A review. Agron. Sustain. Dev. 35, 911-935.

Bender, S.F., Wagg, C., van der Heijden, M.G.A., 2016. An underground revolution: biodiversity and soil ecological engineering for agricultural sustainability. Trends Ecol. Evol. 31, 440-452.

Blaauw, B.R., Isaacs, R., 2014. Flower plantings increase wild bee abundance and the pollination services provided to a pollination-dependent crop. J. Appl. Ecol. 51, 890-898.

Blouin, M., Hodson, M.E., Delgado, E.A., Baker, G., Brussaard, L., Butt, K.R., Dai, J., Dendooven, L., Peres, G., Tondoh, J.E., Cluzeau, D., Brun, J.J., 2013. A review of earthworm impact on soil function and ecosystem services. Eur. J. Soil Sci. 64, 161-182.

Bommarco, R., Biesmeijer, J.C., Meyer, B., Potts, S.G., Poyry, J., Roberts, S.P.M., SteffanDewenter, I., Ockinger, E., 2010. Dispersal capacity and diet breadth modify the response of wild bees to habitat loss. Proc. R. Soc. B Biol. Sci. 277, 2075-2082.

Bommarco, R., Kleijn, D., Potts, S.G., 2013. Ecological intensification: harnessing ecosystem services for food security. Trends Ecol. Evol. 28, 230-238.

Breeze, T.D., Vaissière, B.E., Bommarco, R., Petanidou, T., Seraphides, N., Kozák, L., Scheper, J., Biesmeijer, J.C., Kleijn, D., Gyldenkærne, S., Moretti, M., Holzschuh, A., Steffan-Dewenter, I., Stout, J.C., Pärtel, M., Zobel, M., Potts, S.G., 2014. Agricultural policies exacerbate honeybee pollination service supply-demand mismatches across Europe. PLoS One 9, e82996.

Brittain, C., Bommarco, R., Vighi, M., Settele, J., Potts, S.G., 2010. Organic farming in isolated landscapes does not benefit flower-visiting insects and pollination. Biol. Conserv. 143, 1860-1867.

Brittain, C., Williams, N., Kremen, C., Klein, A.-M., 2013. Synergistic effects of non-Apis bees and honey bees for pollination services. Proc. R. Soc. B 280, 20122767.

Brooker, R.W., Bennett, A.E., Cong, W.F., Daniell, T.J., George, T.S., Hallett, P.D., Hawes, C., Iannetta, P.P.M., Jones, H.G., Karley, A.J., Li, L., McKenzie, B.M., Pakeman, R.J., Paterson, E., Schob, C., Shen, J.B., Squire, G., Watson, C.A., Zhang, C.C., Zhang, F.S., Zhang, J.L., White, P.J., 2015. Improving intercropping: a synthesis of research in agronomy, plant physiology and ecology. New Phytol. 206, 107-117.

Burkle, L.A., Marlin, J.C., Knight, T.M., 2013. Plant-pollinator interactions over 120 years: loss of species, co-occurrence, and function. Science 339, 1611-1615.

Butler, J.R.A., Young, J.C., Marzano, M., 2019. Adaptive co-management and conflict resolution for rewilding across development contexts. In: Pettorelli, N., Durant, S., du Toit, J. (Eds.), Rewilding. Ecological Reviews, Cambridge University Press, p. 386.

Caron, P., de y Loma-Osorio, G.F., Nabarro, D., Hainzelin, E., Guillou, M., Andersen, I., Arnold, T., Astralaga, M., Beukeboom, M., Bickersteth, S., 2018. Food systems for sustainable development: proposals for a profound four-part transformation. Agron. Sustain. Dev. 38, 41. 
Carvell, C., Bourke, A.F.G., Dreier, S., Freeman, S.N., Hulmes, S., Jordan, W.C., Redhead, J.W., Sumner, S., Wang, J., Heard, M.S., 2017. Bumblebee family lineage survival is enhanced in high-quality landscapes. Nature 543, 547-549.

Catarino, R., Bretagnolle, V., Perrot, T., Vialloux, F., Gaba, S., 2019. Bee pollination outperforms pesticides for oilseed crop production and profitability. Proc. R. Soc. B Biol. Sci. 286, 20191550.

CBD, 2014. Secretariat of the Convention on Biological Diversity. Global Biodiversity Outlook 4, Montréal, p. 155.

Chagnon, M., Kreutzweiser, D., Mitchell, E.A., Mitchell, E.A., Morrissey, C.A., Noome, D.A., Noome, D.A., Van der Sluijs, J.P., Van der Sluijs, J.P., 2015. Risks of large-scale use of systemic insecticides to ecosystem functioning and services. Environ. Sci. Pollut. Res. 22, 119-134.

Chandra, A., McNamara, K.E., Dargusch, P., 2017. The relevance of political ecology perspectives for smallholder Climate-Smart Agriculture: a review. J. Polit. Econ. 24, 821-842.

Chaplin-Kramer, R., Sharp, R.P., Weil, C., Bennett, E.M., Pascual, U., Arkema, K.K., Brauman, K.A., Bryant, B.P., Guerry, A.D., Haddad, N.M., Hamann, M., Hamel, P., Johnson, J.A., Mandle, L., Pereira, H.M., Polasky, S., Ruckelshaus, M., Shaw, M.R., Silver, J.M., Vogl, A.L., Daily, G.C., 2019. Global modeling of nature's contributions to people. Science 366, 255-258.

Chen, K.L., Wang, Y.P., Zhang, R., Zhang, H.W., Gao, C.X., 2019. CRISPR/Cas genome editing and precision plant breeding in agriculture. In: Merchant, S.S. (Ed.), Annual Review of Plant Biology. vol. 70. Annual Reviews, pp. 667-697.

Colbach, N., Cordeau, S., 2018. Reduced herbicide use does not increase crop yield loss if it is compensated by alternative preventive and curative measures. Eur. J. Agron. 94, $67-78$.

Cordeau, S., Guillemin, J.P., Reibel, C., Chauvel, B., et al., 2015. Weed species differ in their ability to emerge in no-till systems that include cover crops. Ann. Appl. Biol. 128, 271-273.

Corlett, R.T., 2016. Restoration, reintroduction, and rewilding in a changing world. Trends Ecol. Evol. 31, 453-462.

Coz, D., Young, J.C., 2020. Conflicts over wildlife conservation: learning from the reintroduction of beavers in Scotland. People Nat. 2, 406-419.

Dainese, M., Montecchiari, S., Sitzia, T., Sigura, M., Marini, L., 2017. High cover of hedgerows in the landscape supports multiple ecosystem services in Mediterranean cereal fields. J. Appl. Ecol. 54, 380-388.

Dainese, M., Martin, E.A., Aizen, M.A., Albrecht, M., Bartomeus, I., Bommarco, R., Carvalheiro, L.G., Chaplin-Kramer, R., Gagic, V., Garibaldi, L.A., Ghazoul, J., Grab, H., Jonsson, M., Karp, D.S., Kennedy, C.M., Kleijn, D., Kremen, C., Landis, D.A., Letourneau, D.K., Marini, L., Poveda, K., Rader, R., Smith, H.G., Tscharntke, T., Andersson, G.K.S., Badenhausser, I., Baensch, S., Bezerra, A.D.M., Bianchi, F.J.J.A., Boreux, V., Bretagnolle, V., Caballero-Lopez, B., Cavigliasso, P., Ćetković, A., Chacoff, N.P., Classen, A., Cusser, S., da Silva e Silva, F.D., de Groot, G.A., Dudenhöffer, J.H., Ekroos, J., Fijen, T., Franck, P., Freitas, B.M., Garratt, M.P.D., Gratton, C., Hipólito, J., Holzschuh, A., Hunt, L., Iverson, A.L., Jha, S., Keasar, T., Kim, T.N., Kishinevsky, M., Klatt, B.K., Klein, A.-M., Krewenka, K.M., Krishnan, S., Larsen, A.E., Lavigne, C., Liere, H., Maas, B., Mallinger, R.E., Martinez Pachon, E., Martínez-Salinas, A., Meehan, T.D., Mitchell, M.G.E., Molina, G.A.R., Nesper, M., Nilsson, L., O'Rourke, M.E., Peters, M.K., Plećaš, M., Potts, S.G., Ramos, D.D.L., Rosenheim, J.A., Rundlöf, M., Rusch, A., Sáez, A., Scheper, J., Schleuning, M., Schmack, J.M., Sciligo, A.R., Seymour, C., Stanley, D.A., Stewart, R., Stout, J.C., Sutter, L., Takada, M.B., Taki, H., Tamburini, G., Tschumi, M., Viana, B.F., Westphal, C., Willcox, B.K., 
Wratten, S.D., Yoshioka, A., Zaragoza-Trello, C., Zhang, W., Zou, Y., et al., 2019. A global synthesis reveals biodiversity-mediated benefits for crop production. Sci. Adv. 5, eaax0121.

d'Amour, C.B., Reitsma, F., Baiocchi, G., Barthel, S., Güneralp, B., Erb, K.-H., Haberl, H., Creutzig, F., Seto, K.C., 2017. Future urban land expansion and implications for global croplands. Proc. Natl. Acad. Sci. U. S. A. 114, 8939-8944.

Dawson, I.K., Powell, W., Hendre, P., Bančič, J., Hickey, J.M., Kindt, R., Hoad, S., Hale, I., Jamnadass, R., 2019. The role of genetics in mainstreaming the production of new and orphan crops to diversify food systems and support human nutrition. New Phytol. 224, 37-54.

de Ponti, T., Rijk, B., van Ittersum, M.K., 2012. The crop yield gap between organic and conventional agriculture. Agr. Syst. 108, 1-9.

de Vries, F.T., Thebault, E., Liiri, M., Birkhofer, K., Tsiafouli, M.A., Bjornlund, L., Jorgensen, H.B., Brady, M.V., Christensen, S., de Ruiter, P.C., d'Hertefeldt, T., Frouz, J., Hedlund, K., Hemerik, L., Hol, W.H.G., Hotes, S., Mortimer, S.R., Setala, H., Sgardelis, S.P., Uteseny, K., van der Putten, W.H., Wolters, V., Bardgett, R.D., 2013. Soil food web properties explain ecosystem services across European land use systems. Proc. Natl. Acad. Sci. U. S. A. 110, 14296-14301.

Deguines, N., Jono, C., Baude, M., Henry, M., Julliard, R., Fontaine, C., 2014. Large-scale trade-off between agricultural intensification and crop pollination services. Front. Ecol. Environ. 12, 212-217.

DeLonge, M.S., Miles, A., Carlisle, L., 2016. Investing in the transition to sustainable agriculture. Environ. Sci. Policy 55 (Pt. 1), 266-273.

Dentoni, D., Waddell, S., Waddock, S., 2017. Pathways of transformation in global food and agricultural systems: implications from a large systems change theory perspective. Curr. Opin. Environ. Sustain. 29, 8-13.

Díaz, S., Pascual, U., Stenseke, M., Martín-López, B., Watson, R.T., Molnár, Z., Hill, R., Chan, K.M.A., Baste, I.A., Brauman, K.A., Polasky, S., Church, A., Lonsdale, M., Larigauderie, A., Leadley, P.W., van Oudenhoven, A.P.E., van der Plaat, F., Schröter, M., Lavorel, S., Aumeeruddy-Thomas, Y., Bukvareva, E., Davies, K., Demissew, S., Erpul, G., Failler, P., Guerra, C.A., Hewitt, C.L., Keune, H., Lindley, S., Shirayama, Y., 2018. Assessing nature's contributions to people. Science 359, 270-272.

Dirzo, R., Young, H.S., Galetti, M., Ceballos, G., Isaac, N.J.B., Collen, B., 2014. Defaunation in the Anthropocene. Science 345, 401-406.

Dominik, C., Seppelt, R., Horgan, F.G., Settele, J., Václavík,, T., et al., 2018. Landscape composition, configuration, and trophic interactions shape arthropod communities in rice agroecosystems. J. Appl. Ecol. 55, 2461-2472.

Dowd, A.-M., Marshall, N., Fleming, A., Jakku, E., Gaillard, E., Howden, M., 2014. The role of networks in transforming Australian agriculture. Nat. Clim. Chang. 4, $558-563$.

Eggleton, P., Vanbergen, A.J., Jones, D.T., Lambert, M.C., Rockett, C., Hammond, P.M., Beccaloni, J., Marriott, D., Ross, E., Giusti, A., 2005. Assemblages of soil macrofauna across a Scottish land-use intensification gradient: influences of habitat quality, heterogeneity and area. J. Appl. Ecol. 42, 1153-1164.

Ehler, L.E., 2006. Integrated pest management (IPM): definition, historical development and implementation, and the other IPM. Pest Manag. Sci. 62, 787-789.

Ellis, E.C., Goldewijk, K.K., Siebert, S., Lightman, D., Ramankutty, N., 2010. Anthropogenic transformation of the biomes, 1700 to 2000. Glob. Ecol. Biogeogr. 19, 589-606.

FAO, 2015. A Data Portrait of Smallholder Farmers. [Online]. Available: http://www.fao. org/family-farming/detail/fr/c/1111162/. (Accessed 20 March 2020). 
FAO, 2016. Organic Agriculture. [Online]. Available http://www.fao.org/organicag/ oa-faq/oa-faq1/en/. (Accessed 4 February 2016).

FAOSTAT, 2017. Selected Indicators: Africa. [Online]. Available http://faostat.fao.org/ static/syb/syb_5100.pdf. (Accessed).

Feltham, H., Park, K., Minderman, J., Goulson, D., 2015. Experimental evidence that wildflower strips increase pollinator visits to crops. Ecol. Evol. 5, 3523-3530.

Feola, G., 2015. Societal transformation in response to global environmental change: a review of emerging concepts. Ambio 44, 376-390.

Fermont, A.M., van Asten, P.J.A., Tittonell, P., van Wijk, M.T., Giller, K.E., 2009. Closing the cassava yield gap: an analysis from smallholder farms in East Africa. Field Crop Res. $112,24-36$.

Foley, J.A., DeFries, R., Asner, G.P., Barford, C., Bonan, G., Carpenter, S.R., Chapin, F.S., Coe, M.T., Daily, G.C., Gibbs, H.K., Helkowski, J.H., Holloway, T., Howard, E.A., Kucharik, C.J., Monfreda, C., Patz, J.A., Prentice, I.C., Ramankutty, N., Snyder, P.K., 2005. Global consequences of land use. Science 309, 570-574.

Gagic, V., Kleijn, D., Baldi, A., Boros, G., Jorgensen, H.B., Elek, Z., Garratt, M.P.D., de Groot, G.A., Hedlund, K., Kovacs-Hostyanszki, A., Marini, L., Martin, E., Pevere, I., Potts, S.G., Redlich, S., Senapathi, D., Steffan-Dewenter, I., Switek, S., Smith, H.G., Takacs, V., Tryjanowski, P., van der Putten, W.H., van Gils, S., Bommarco, R., 2017. Combined effects of agrochemicals and ecosystem services on crop yield across Europe. Ecol. Lett. 20, 1427-1436.

Gallé, R., Happe, A.K., Baillod, A.B., Tscharntke, T., Batary, P., 2019. Landscape configuration, organic management, and within-field position drive functional diversity of spiders and carabids. J. Appl. Ecol. 56, 63-72.

Garibaldi, L.A., Steffan-Dewenter, I., Kremen, C., Morales, J.M., Bommarco, R., Cunningham, S., Carvalheiro, L., Chacoff, N., Dudenhöffer, J.H., Greenleaf, S., Holzschuh, A., Isaacs, R., Krewenka, K., Mandelik, Y., Mayfield, M., Morandin, L., Potts, S.G., Ricketts, T., Szentgyörgyi, H., Winfree, R., Klein, A.M., 2011. Stability of pollination services decreases with isolation from natural areas despite honey bee visits. Ecol. Lett. 14, 1062-1072.

Garibaldi, L.A., Steffan-Dewenter, I., Winfree, R., Aizen, M.A., Bommarco, R., Cunningham, S.A., Kremen, C., Carvalheiro, L.G., Harder, L.D., Afik, O., Bartomeus, I., Benjamin, F., Boreux, V., Cariveau, D., Chacoff, N.P., Dudenhöffer, J.H., Freitas, B.M., Ghazoul, J., Greenleaf, S., Hipólito, J., Holzschuh, A., Howlett, B., Isaacs, R., Javorek, S.K., Kennedy, C.M., Krewenka, K., Krishnan, S., Mandelik, Y., Mayfield, M.M., Motzke, I., Munyuli, T., Nault, B.A., Otieno, M., Petersen, J., Pisanty, G., Potts, S.G., Rader, R., Ricketts, T.H., Rundlöf, M., Seymour, C.L., Schüepp, C., Szentgyörgyi, H., Taki, H., Tscharntke, T., Vergara, C.H., Viana, B.F., Wanger, T.C., Westphal, C., Williams, N., Klein, A.M., 2013. Wild pollinators enhance fruit set of crops regardless of honey bee abundance. Science 339, 1608-1611.

Garibaldi, L.A., Bartomeus, I., Bommarco, R., Klein, A.M., Cunningham, S.A., Aizen, M.A., Boreux, V., Garratt, M.P.D., Carvalheiro, L.G., Kremen, C., Morales, C.L., Schüepp, C., Chacoff, N.P., Freitas, B.M., Gagic, V., Holzschuh, A., Klatt, B.K., Krewenka, K.M., Krishnan, S., Mayfield, M.M., Motzke, I., Otieno, M., Petersen, J., Potts, S.G., Ricketts, T.H., Rundlöf, M., Sciligo, A., Sinu, P.A., Steffan-Dewenter, I., Taki, H., Tscharntke, T., Vergara, C.H., Viana, B.F., Woyciechowski, M., 2015. Trait matching of flower visitors and crops predicts fruit set better than trait diversity. J. Appl. Ecol. 52, 1436-1444.

Garibaldi, L.A., Carvalheiro, L.G., Vaissière, B.E., Gemmill-Herren, B., Hipólito, J., Freitas, B.M., Ngo, H.T., Azzu, N., Sáez, A., Åström, J., An, J., Blochtein, B., Buchori, D., García, F.J.C., Oliveira da Silva, F., Devkota, K., Ribeiro, M.D.F., 
Freitas, L., Gaglianone, M.C., Goss, M., Irshad, M., Kasina, M., Filho, A.J.S.P., Kiill, L.H.P., Kwapong, P., Parra, G.N., Pires, C., Pires, V., Rawal, R.S., Rizali, A., Saraiva, A.M., Veldtman, R., Viana, B.F., Witter, S., Zhang, H., 2016. Mutually beneficial pollinator diversity and crop yield outcomes in small and large farms. Science 351, 388-391.

Garibaldi, L.A., Gemmill-Herren, B., D’Annolfo, R., Graeub, B.E., Cunningham, S.A., Breeze, T.D., 2017. Farming approaches for greater biodiversity, livelihoods, and food security. Trends Ecol. Evol. 32, 68-80.

Garibaldi, L.A., Pérez-Méndez, N., Garratt, M.P.D., Gemmill-Herren, B., Miguez, F.E., Dicks, L.V., 2019. Policies for ecological intensification of crop production. Trends Ecol. Evol. 34, 282-286.

Garnett, T., Appleby, M.C., Balmford, A., Bateman, I.J., Benton, T.G., Bloomer, P., Burlingame, B., Dawkins, M., Dolan, L., Fraser, D., 2013. Sustainable intensification in agriculture: premises and policies. Science 341, 33-34.

Garratt, M., Wright, D., Leather, S., 2011. The effects of farming system and fertilisers on pests and natural enemies: a synthesis of current research. Agric. Ecosyst. Environ. 141, 261-270.

Garratt, M.P., Senapathi, D., Coston, D.J., Mortimer, S.R., Potts, S.G., 2017. The benefits of hedgerows for pollinators and natural enemies depends on hedge quality and landscape context. Agric. Ecosyst. Environ. 247, 363-370.

Garratt, M.P., Bishop, J., Degani, E., Potts, S.G., Shaw, R.F., Shi, A., Roy, S., 2018a. Insect pollination as an agronomic input: strategies for oilseed rape production. J. Appl. Ecol. 55, 2834-2842.

Garratt, M.P.D., Bommarco, R., Kleijn, D., Martin, E., Mortimer, S.R., Redlich, S., Senapathi, D., Steffan-Dewenter, I., Świtek, S., Takács, V., van Gils, S., van der Putten, W.H., Potts, S.G., 2018b. Enhancing soil organic matter as a route to the ecological intensification of European arable systems. Ecosystems 21, 1404-1415.

Ghogare, R., Williamson-Benavides, B., Ramirez-Torres, F., Dhingra, A., 2019. CRISPRassociated nucleases: the Dawn of a new age of efficient crop improvement. Transgenic Res. 29, 1-35.

Gil, J.D.B., Garrett, R.D., Rotz, A., Daioglou, V., Valentim, J., Pires, G.F., Costa, M.H., Lopes, L., Reis, J.C., 2018. Tradeoffs in the quest for climate smart agricultural intensification in Mato Grosso, Brazil. Environ. Res. Lett. 13, 064025.

Giller, K.E., Andersson, J.A., Corbeels, M., Kirkegaard, J., Mortensen, D., Erenstein, O., Vanlauwe, B., 2015. Beyond conservation agriculture. Front. Plant Sci. 6, 870.

Godfray, H.C.J., Beddington, J.R., Crute, I.R., Haddad, L., Lawrence, D., Muir, J.F., Pretty, J., Robinson, S., Thomas, S.M., Toulmin, C., 2010. Food security: the challenge of feeding 9 billion people. Science 327, 812-818.

Godfray, H.C.J., Blacquière, T., Field, L.M., Hails, R.S., Petrokofsky, G., Potts, S.G., Raine, N.E., Vanbergen, A.J., McLean, A.R., 2014. A restatement of the natural science evidence base concerning neonicotinoid insecticides and insect pollinators. Proc. R. Soc. B Biol. Sci. 281, 20140558.

Gomiero, T., Pimentel, D., Paoletti, M.G., 2011. Environmental impact of different agricultural management practices: conventional vs. organic agriculture. Crit. Rev. Plant Sci. 30, 95-124.

Grass, I., Batáry, P., Tscharntke, T., in press. Combining land-sparing and land-sharing in European landscapes. Adv. Ecol. Res. 64.

Greenleaf, S.S., Kremen, C., 2006. Wild bees enhance honey bees' pollination of hybrid sunflower. Proc. Natl. Acad. Sci. U. S. A. 103, 13890-13895.

Griffiths, C.A., Sagar, R., Geng, Y., Primavesi, L.F., Patel, M.K., Passarelli, M.K., Gilmore, I.S., Steven, R.T., Bunch, J., Paul, M.J., Davis, B.G., 2016. Chemical intervention in plant sugar signalling increases yield and resilience. Nature 540, 574-578. 
Gurr, G.M., Wratten, S.D., Altieri, M.A., et al., 2004. Ecological engineering: a new direction for agricultural pest management. AFBM J. 1, 28-35.

Gurr, G.M., Zhongxian, L., Zheng, X., Xu, H., Zhu, P., Chen, G., Yao, X., Cheng, J., Zhu, Z., Catindig, J.L., Villareal, S., Van Chien, H., Cuong, LQ., Channoo, C., Chengwattana, N., Lan, LP., Hai, LH., Chaiwong, J., Nicol, H.I., Perovic, D.J., Wratten, S.D., Heong, K.L., 2016. Multi-country evidence that crop diversification promotes ecological intensification of agriculture. Nat. Plants 2, 16014.

Guthman, J., 2014. Agrarian Dreams: The Paradox of Organic Farming in California. University of California Press.

Hass, A.L., Kormann, U.G., Tscharntke, T., Clough, Y., Baillod, A.B., Sirami, C., Fahrig, L., Martin, J.L., Baudry, J., Bertrand, C., Bosch, J., Brotons, L., Burel, F., Georges, R., Giralt, D., Marcos-Garcia, M.A., Ricarte, A., Siriwardena, G., Batary, P., 2018. Landscape configurational heterogeneity by small-scale agriculture, not crop diversity, maintains pollinators and plant reproduction in western Europe. Proc. R. Soc. B Biol. Sci. 285, 20172242.

Henle, K., Alard, D., Clitherow, J., Cobb, P., Firbank, L., Kull, T., McCracken, D., Moritz, R.F., Niemelä, J., Rebane, M., 2008. Identifying and managing the conflicts between agriculture and biodiversity conservation in Europe-a review. Agric. Ecosyst. Environ. 124, 60-71.

Herrero, M., Thornton, P.K., Notenbaert, A.M., Wood, S., Msangi, S., Freeman, H., Bossio, D., Dixon, J., Peters, M., van de Steeg, J., 2010. Smart investments in sustainable food production: revisiting mixed crop-livestock systems. Science 327, 822-825.

Herrero, M., Thornton, P.K., Power, B., Bogard, J.R., Remans, R., Fritz, S., Gerber, J.S., Nelson, G., See, L., Waha, K., 2017. Farming and the geography of nutrient production for human use: a transdisciplinary analysis. Lancet Planet. Health 1, e33-e42.

Hill, S.B., MacRae, R.J., 1996. Conceptual framework for the transition from conventional to sustainable agriculture. J. Sustain. Agric. 7, 81-87.

Hill, R., Nates-Parra, G., Quezada-Euán, J.J.G., Buchori, D., LeBuhn, G., Maués, M.M., Pert, P.L., Kwapong, P.K., Saeed, S., Breslow, S.J., Carneiro da Cunha, M., Dicks, L.V., Galetto, L., Gikungu, M., Howlett, B.G., Imperatriz-Fonseca, V.L., Lyver, P.O.‘.B., Martín-López, B., Oteros-Rozas, E., Potts, S.G., Roué, M., 2019. Biocultural approaches to pollinator conservation. Nat. Sustain. 2, 214-222.

Hoehn, P., Tscharntke, T., Tylianakis, J.M., Steffan-Dewenter, I., 2008. Functional group diversity of bee pollinators increases crop yield. Proc. R. Soc. B Biol. Sci. 275, 2283-2291.

Hoggart, K., Paniagua, A., 2001. The restructuring of rural Spain? J. Rural. Stud. 17, 63-80.

Hole, D.G., Perkins, A., Wilson, J., Alexander, I., Grice, P., Evans, A.D., 2005. Does organic farming benefit biodiversity? Biol. Conserv. 122, 113-130.

Holzschuh, A., Steffan-Dewenter, I., Tscharntke, T., 2008. Agricultural landscapes with organic crops support higher pollinator diversity. Oikos 117, 354-361.

Horgan, F.G., Ramal, A.F., Bernal, C.C., Villegas, J.M, Stuart, A.M., Almazan, M.L., 2016. Applying ecological engineering for sustainable and resilient rice production systems. Proc. Food Sci. 6, 7-15.

Horgan, F.G., Ramal, A.F., Villegas, J.M., Jamoralin, A., Bernal, C.C., Perez, M.O., Pasang, J.M., Naredo, A.I., Almazan, M.L.P., et al., 2017. Effects of bund crops and insecticide treatments on arthropod diversity and herbivore regulation in tropical rice fields. J. Appl. Entomol. 141, 587-599.

Horst, M., McClintock, N., Hoey, L., 2017. The intersection of planning, Urban agriculture, and food justice a review of the literature. J. Am. Plann. Assoc. 83, 277-295.

Hung, K.-L.J., Kingston, J.M., Albrecht, M., Holway, D.A., Kohn, J.R., 2018. The worldwide importance of honey bees as pollinators in natural habitats. Proc. R. Soc. B Biol. Sci. 285, 20172140. 
IPBES, 2016. The assessment report of the Intergovernmental Science-Policy Platform on Biodiversity and Ecosystem Services on pollinators, pollination and food production. In: Potts, S.G., Imperatriz-Fonseca, V.L., Ngo, H.T. (Eds.), Secretariat of the Intergovernmental Science-Policy Platform on Biodiversity and Ecosystem Services, Bonn, Germany.

IPBES, 2019. Summary for policymakers of the global assessment report of the Intergovernmental Science-Policy Platform on Biodiversity and Ecosystem Services. Secretariat of the Intergovernmental Science-Policy Platform on Biodiversity and Ecosystem Services, Bonn, Germany.

IPCC, 2019. Climate Change and Land: an IPCC special report on climate change, desertification, land degradation, sustainable land management, food security, and greenhouse gas fluxes in terrestrial ecosystems. In: Shukla, P.R., Skea, J., Calvo Buendia, E., MassonDelmotte, V., Pörtner, H.-O., Roberts, D.C., Zhai, P., Slade, R., Connors, S., van Diemen, R., Ferrat, M., Haughey, E., Luz, S., Neogi, S., Pathak, M., Petzold, J., Portugal Pereira, J., Vyas, P., Huntley, E., Kissick, K., Belkacemi, M., Malley, J. (Eds.), In press.

Iverson, A.L., Marín, L.E., Ennis, K.K., Gonthier, D.J., Connor-Barrie, B.T., Remfert, J.L., Cardinale, B.J., Perfecto, I., 2014. Do polycultures promote win-wins or trade-offs in agricultural ecosystem services? A meta-analysis. J. Appl. Ecol. 51, 1593-1602.

Jost, C., Kyazze, F., Naab, J., Neelormi, S., Kinyangi, J., Zougmore, R., Aggarwal, P., Bhatta, G., Chaudhury, M., Tapio-Bistrom, M.L., Nelson, S., Kristjanson, P., 2016. Understanding gender dimensions of agriculture and climate change in smallholder farming communities. Clim. Dev. 8, 133-144.

Karp, D.S., Chaplin-Kramer, R., Meehan, T.D., Martin, E.A., DeClerck, F., Grab, H., Gratton, C., Hunt, L., Larsen, A.E., Martínez-Salinas, A., O’Rourke, M.E., Rusch, A., Poveda, K., Jonsson, M., Rosenheim, J.A., Schellhorn, N.A., Tscharntke, T., Wratten, S.D., Zhang, W., Iverson, A.L., Adler, L.S., Albrecht, M., Alignier, A., Angelella, G.M., Zubair Anjum, M., Avelino, J., Batáry, P., Baveco, J.M., Bianchi, F.J.J.A., Birkhofer, K., Bohnenblust, E.W., Bommarco, R., Brewer, M.J., Caballero-López, B., Carrière, Y., Carvalheiro, L.G., Cayuela, L., Centrella, M., Ćetković, A., Henri, D.C., Chabert, A., Costamagna, A.C., De la Mora, A., de Kraker, J., Desneux, N., Diehl, E., Diekötter, T., Dormann, C.F., Eckberg, J.O., Entling, M.H., Fiedler, D., Franck, P., Frank van Veen, F.J., Frank, T., Gagic, V., Garratt, M.P.D., Getachew, A., Gonthier, D.J., Goodell, P.B., Graziosi, I., Groves, R.L., Gurr, G.M., Hajian-Forooshani, Z., Heimpel, G.E., Herrmann, J.D., Huseth, A.S., Inclán, D.J., Ingrao, A.J., Iv, P., Jacot, K., Johnson, G.A., Jones, L., Kaiser, M., Kaser, J.M., Keasar, T., Kim, T.N., Kishinevsky, M., Landis, D.A., Lavandero, B., Lavigne, C., Le Ralec, A., Lemessa, D., Letourneau, D.K., Liere, H., Lu, Y., Lubin, Y., Luttermoser, T., Maas, B., Mace, K., Madeira, F., Mader, V., Cortesero, A.M., Marini, L., Martinez, E., Martinson, H.M., Menozzi, P., Mitchell, M.G.E., Miyashita, T., Molina, G.A.R., Molina-Montenegro, M.A., et al., 2018. Crop pests and predators exhibit inconsistent responses to surrounding landscape composition. Proc. Natl. Acad. Sci. U. S. A. 115, E7863-E7870.

Katayama, N., Osada, Y., Mashiko, M., Baba, Y.G., Tanaka, K., Kusumoto, Y., Okubo, S., Ikeda, H., Natuhara, Y., 2019. Organic farming and associated management practices benefit multiple wildlife taxa: a large-scale field study in rice paddy landscapes. J. Appl. Ecol. 56, 1970-1981.

Kennedy, C.M., Lonsdorf, E., Neel, M.C., Williams, N.M., Ricketts, T.H., Winfree, R., Bommarco, R., Brittain, C., Burley, A.L., Cariveau, D., Carvalheiro, L.G., Chacoff, N.P., Cunningham, S.A., Danforth, B.N., Dudenhöffer, J.-H., Elle, E., 
Gaines, H.R., Garibaldi, L.A., Gratton, C., Holzschuh, A., Isaacs, R., Javorek, S.K., Jha, S., Klein, A.M., Krewenka, K., Mandelik, Y., Mayfield, M.M., Morandin, L., Neame, L.A., Otieno, M., Park, M., Potts, S.G., Rundlöf, M., Saez, A., SteffanDewenter, I., Taki, H., Viana, B.F., Westphal, C., Wilson, J.K., Greenleaf, S.S., Kremen, C., 2013. A global quantitative synthesis of local and landscape effects on wild bee pollinators in agroecosystems. Ecol. Lett. 16, 584-599.

Kleijn, D., Winfree, R., Bartomeus, I., Carvalheiro, L.G., Henry, M., Isaacs, R., Klein, A.M., Kremen, C., M'Gonigle, L.K., Rader, R., Ricketts, T.H., Williams, N.M., Lee Adamson, N., Ascher, J.S., Baldi, A., Batary, P., Benjamin, F., Biesmeijer, J.C., Blitzer, E.J., Bommarco, R., Brand, M.R., Bretagnolle, V., Button, L., Cariveau, D.P., Chifflet, R., Colville, J.F., Danforth, B.N., Elle, E., Garratt, M.P.D., Herzog, F., Holzschuh, A., Howlett, B.G., Jauker, F., Jha, S., Knop, E., Krewenka, K.M., Le Feon, V., Mandelik, Y., May, E.A., Park, M.G., Pisanty, G., Reemer, M., Riedinger, V., Rollin, O., Rundlof, M., Sardinas, H.S., Scheper, J., Sciligo, A.R., Smith, H.G., Steffan-Dewenter, I., Thorp, R., Tscharntke, T., Verhulst, J., Viana, B.F., Vaissiere, B.E., Veldtman, R., Westphal, C., Potts, S.G., 2015. Delivery of crop pollination services is an insufficient argument for wild pollinator conservation. Nat. Commun. 6, 7414.

Kleijn, D., Bommarco, R., Fijen, T.P.M., Garibaldi, L.A., Potts, S.G., van der Putten, W.H., 2019. Ecological intensification: bridging the gap between science and practice. Trends Ecol. Evol. 34, 154-166.

Klein, A.-M., Brittain, C., Hendrix, S.D., Thorp, R., Williams, N., Kremen, C., 2012. Wild pollination services to California almond rely on semi-natural habitat. J. Appl. Ecol. 49, 723-732.

Kogan, M., 1998. Integrated pest management: historical perspectives and contemporary developments. Annu. Rev. Entomol. 43, 243-270.

Kovács-Hostyánszki, A., Espíndola, A., Vanbergen, A.J., Settele, J., Kremen, C., Dicks, L.V., 2017. Ecological intensification to mitigate impacts of conventional intensive land use on pollinators and pollination. Ecol. Lett. 20, 673-689.

Krauss, J., Gallenberger, I., Steffan-Dewenter, I., 2011. Decreased functional diversity and biological pest control in conventional compared to organic crop fields. PLoS One 6, e19502.

Kremen, C., Miles, A., 2012. Ecosystem services in biologically diversified versus conventional farming systems: benefits, externalities, and trade-offs. Ecol. Soc. 17, 40.

Kremen, C., Iles, A., Bacon, C., 2012. Diversified farming systems: an agroecological, systems-based alternative to modern industrial agriculture. Ecol. Soc. 17, 44.

Lal, R., 2006. Enhancing crop yields in the developing countries through restoration of the soil organic carbon pool in agricultural lands. Land Degrad. Dev. 17, 197-209.

Landis, D.A., 2017. Designing agricultural landscapes for biodiversity-based ecosystem services. Basic Appl. Ecol. 18, 1-12.

Landis, D.A., Wratten, S.D., Gurr, G.M., 2000. Habitat management to conserve natural enemies of arthropod pests in agriculture. Ann. Rev. Entomol. 45, 175-201.

Lange, M., Eisenhauer, N., Sierra, C.A., Bessler, H., Engels, C., Griffiths, R.I., MelladoVazquez, P.G., Malik, A.A., Roy, J., Scheu, S., Steinbeiss, S., Thomson, B.C., Trumbore, S.E., Gleixner, G., 2015. Plant diversity increases soil microbial activity and soil carbon storage. Nat. Commun. 6, 6707.

Lemaire, G., Franzluebbers, A., Carvalho, P.C.D., Dedieu, B., 2014. Integrated croplivestock systems: strategies to achieve synergy between agricultural production and environmental quality. Agric. Ecosyst. Environ. 190, 4-8.

Letourneau, D.K., Jedlicka, J.A., Bothwell, S.G., Moreno, C.R., 2009. Effects of natural enemy biodiversity on the suppression of arthropod herbivores in terrestrial ecosystems. Annu. Rev. Ecol. Evol. Syst. 40, 573-592. 
Liakos, K.G., Busato, P., Moshou, D., Pearson, S., Bochtis, D., 2018. Machine learning in agriculture: a review. Sensors 18, 2674.

Liere, H., Kim, T.N., Werling, B.P., Meehan, T.D., Landis, D.A., Gratton, C., 2015. Trophic cascades in agricultural landscapes: indirect effects of landscape composition on crop yield. Ecol. Appl. 25, 652-661.

Lin, B.B., 2011. Resilience in agriculture through crop diversification: adaptive management for environmental change. Bioscience 61, 183-193.

Lobell, D.B., Schlenker, W., Costa-Roberts, J., 2011. Climate trends and global crop production since 1980. Science 333, 616-620.

Long, T.B., Blok, V., Coninx, I., 2016. Barriers to the adoption and diffusion of technological innovations for climate-smart agriculture in Europe: evidence from the Netherlands, France, Switzerland and Italy. J. Clean. Prod. 112, 9-21.

Loos, J., Abson, D.J., Chappell, M.J., Hanspach, J., Mikulcak, F., Tichit, M., Fischer, J., 2014. Putting meaning back into "sustainable intensification". Front. Ecol. Environ. 12, 356-361.

Lorimer, J., Sandom, C., Jepson, P., Doughty, C., Barua, M., Kirby, K.J., 2015. Rewilding: science, practice, and politics. Annu. Rev. Env. Resour. 40, 39-62.

Lowder, S.K., Sánchez, M.V., Bertini, R., 2019. Farms, family farms, farmland distribution and farm labour: what do we know today? In: FAO Agricultural Development Economics Working Paper 19-08. FAO, Rome.

Malezieux, E., Crozat, Y., Dupraz, C., Laurans, M., Makowski, D., Ozier-Lafontaine, H., Rapidel, B., de Tourdonnet, S., Valantin-Morison, M., 2009. Mixing plant species in cropping systems: concepts, tools and models. A review. Agron. Sustain. Dev. 29, 43-62.

Mann, C., Jeanneaux, P., 2009. Two approaches for understanding land-use conflict to improve rural planning and management. J. Rural Community Dev. 4, 118-141.

Marini, L., Öckinger, E., Bergman, K.-O., Jauker, B., Krauss, J., Kuussaari, M., Pöyry, J., Smith, H.G., Steffan-Dewenter, I., Bommarco, R., 2014. Contrasting effects of habitat area and connectivity on evenness of pollinator communities. Ecography 37, 544-551.

Marshall, N.A., Dowd, A.-M., Fleming, A., Gambley, C., Howden, M., Jakku, E., Larsen, C., Marshall, P.A., Moon, K., Park, S., 2014. Transformational capacity in Australian peanut farmers for better climate adaptation. Agron. Sustain. Dev. 34, 583-591.

Martin, G., Allain, S., Bergez, J.-E., Burger-Leenhardt, D., Constantin, J., Duru, M., Hazard, L., Lacombe, C., Magda, D., Magne, M.-A., 2018. How to address the sustainability transition of farming systems? A conceptual framework to organize research. Sustainability 10, 2083.

Martin, E.A., Dainese, M., Clough, Y., Báldi, A., Bommarco, R., Gagic, V., Garratt, M.P.D., Holzschuh, A., Kleijn, D., Kovács-Hostyánszki, A., Marini, L., Potts, S.G., Smith, H.G., Al Hassan, D., Albrecht, M., Andersson, G.K.S., Asís, J.D., Aviron, S., Balzan, M.V., Baños-Picón, L., Bartomeus, I., Batáry, P., Burel, F., Caballero-López, B., Concepción, E.D., Coudrain, V., Dänhardt, J., Diaz, M., Diekötter, T., Dormann, C.F., Duflot, R., Entling, M.H., Farwig, N., Fischer, C., Frank, T., Garibaldi, L.A., Hermann, J., Herzog, F., Inclán, D., Jacot, K., Jauker, F., Jeanneret, P., Kaiser, M., Krauss, J., Le Féon, V., Marshall, J., Moonen, A.-C., Moreno, G., Riedinger, V., Rundlöf, M., Rusch, A., Scheper, J., Schneider, G., Schüepp, C., Stutz, S., Sutter, L., Tamburini, G., Thies, C., Tormos, J., Tscharntke, T., Tschumi, M., Uzman, D., Wagner, C., Zubair-Anjum, M., SteffanDewenter, I., 2019. The interplay of landscape composition and configuration: new pathways to manage functional biodiversity and agroecosystem services across Europe. Ecol. Lett. 22, 1083-1094.

Mattick, C.S., Allenby, B.R., IEEE, 2012. Cultured meat: the systemic implications of an emerging technology. In: 2012 IEEE International Symposium on Sustainable Systems and Technology. 
Mayhall, T.A., 2019. The meat of the matter: regulating a laboratory-grown alternative. Food Drug Law J. 74, 151-169.

McDaniel, M., Tiemann, L., Grandy, A., 2014. Does agricultural crop diversity enhance soil microbial biomass and organic matter dynamics? A meta-analysis. Ecol. Appl. 24, $560-570$.

McGill, B.J., Dornelas, M., Gotelli, N.J., Magurran, A.E., 2015. Fifteen forms of biodiversity trend in the Anthropocene. Trends Ecol. Evol. 30, 104-113.

Montoya, D., Haegeman, B., Gaba, S., de Mazancourt, C., Bretagnolle, V., Loreau, M., 2019. Trade-offs in the provisioning and stability of ecosystem services in agroecosystems. Ecol. Appl. 29, e01853.

Moser, S.C., Ekstrom, J.A., 2010. A framework to diagnose barriers to climate change adaptation. Proc. Natl. Acad. Sci. U. S. A. 107, 22026-22031.

Mouat, M.J., Prince, R., Roche, M.M., 2019. Making value out of ethics: the emerging economic geography of lab-grown meat and other animal-free food products. Econ. Geogr. 95, 136-158.

Navarro, L.M., Pereira, H.M., 2012. Rewilding abandoned landscapes in Europe. Ecosystems 15, 900-912.

Newbold, T., Hudson, L.N., Arnell, A.P., Contu, S., De Palma, A., Ferrier, S., Hill, S.L.L., Hoskins, A.J., Lysenko, I., Phillips, H.R.P., Burton, V.J., Chng, C.W.T., Emerson, S., Gao, D., Pask-Hale, G., Hutton, J., Jung, M., Sanchez-Ortiz, K., Simmons, B.I., Whitmee, S., Zhang, H., Scharlemann, J.P.W., Purvis, A., 2016. Has land use pushed terrestrial biodiversity beyond the planetary boundary? A global assessment. Science 353, 288-291.

Nogués-Bravo, D., Simberloff, D., Rahbek, C., Sanders, N.J., 2016. Rewilding is the new Pandora's box in conservation. Curr. Biol. 26, R87-R91.

Nohl, W., 2001. Sustainable landscape use and aesthetic perception-preliminary reflections on future landscape aesthetics. Landsc. Urban Plan. 54, 223-237.

O'Keefe, L., McLachlan, C., Gough, C., Mander, S., Bows-Larkin, A., 2016. Consumer responses to a future UK food system. Br. Food J. 118, 412-428.

Oldfield, E.E., Bradford, M.A., Wood, S.A., 2019. Global meta-analysis of the relationship between soil organic matter and crop yields. Soil 5, 15-32.

O'Rourke, E., 2014. The reintroduction of the white-tailed sea eagle to Ireland: people and wildlife. Land Use Policy 38, 129-137.

Orsini, F., Kahane, R., Nono-Womdim, R., Gianquinto, G., 2013. Urban agriculture in the developing world: a review. Agron. Sustain. Dev. 33, 695-720.

Ort, D.R., Merchant, S.S., Alric, J., Barkan, A., Blankenship, R.E., Bock, R., Croce, R., Hanson, M.R., Hibberd, J.M., Long, S.P., Moore, T.A., Moroney, J., Niyogi, K.K., Parry, M.A.J., Peralta-Yahya, P.P., Prince, R.C., Redding, K.E., Spalding, M.H., van Wijk, K.J., Vermaas, W.F.J., von Caemmerer, S., Weber, A.P.M., Yeates, T.O., Yuan, J.S., Zhu, X.G., 2015. Redesigning photosynthesis to sustainably meet global food and bioenergy demand. Proc. Natl. Acad. Sci. U. S. A. 112, 8529-8536.

Park, S.E., Marshall, N.A., Jakku, E., Dowd, A.M., Howden, S.M., Mendham, E., Fleming, A., 2012. Informing adaptation responses to climate change through theories of transformation. Glob. Environ. Chang. 22, 115-126.

Partel, V., Kakarla, C., Ampatzidis, Y., 2019. Development and evaluation of a low-cost and smart technology for precision weed management utilizing artificial intelligence. Comput. Electron. Agric. 157, 339-350.

Patterson, J., Schulz, K., Vervoort, J., Van Der Hel, S., Widerberg, O., Adler, C., Hurlbert, M., Anderton, K., Sethi, M., Barau, A., 2017. Exploring the governance and politics of transformations towards sustainability. Environ. Innov. Soc. Trans. 24, 1-16.

Pe'er, G., Bonn, A., Bruelheide, H., Dieker, P., Eisenhauer, N., Feindt, P.H., Hagedorn, G., Hansjürgens, B., Herzon, I., Lomba, Â., Marquard, E., Moreira, F., Nitsch, H., 
Oppermann, R., Perino, A., Röder, N., Schleyer, C., Schindler, S., Wolf, C., Zinngrebe, Y., Lakner, S., 2020. Action needed for the EU Common Agricultural Policy to address sustainability challenges. People Nat. 2, 305-316.

Pelling, M., O’Brien, K., Matyas, D., 2015. Adaptation and transformation. Clim. Change 133, 113-127.

Philippot, L., Spor, A., Henault, C., Bru, D., Bizouard, F., Jones, C.M., Sarr, A., Maron, P.A., 2013. Loss in microbial diversity affects nitrogen cycling in soil. ISME J. 7, 1609-1619.

Piesse, J., Thirtle, C., 2010. Agricultural R\&D, technology and productivity. Philos. Trans. R. Soc. B 365, 3035-3047.

Pisa, L.W., Amaral-Rogers, V., Belzunces, L.P., Bonmatin, J.M., Downs, C.A., Goulson, D., Kreutzweiser, D.P., Krupke, C., Liess, M., McField, M., Morrissey, C.A., Noome, D.A., Settele, J., Simon-Delso, N., Stark, J.D., Van der Sluijs, J.P., Van Dyck, H., Wiemers, M., 2015. Effects of neonicotinoids and fipronil on non-target invertebrates. Environ. Sci. Pollut. Res. 22, 68-102.

Ponisio, L.C., M'Gonigle, L.K., Mace, K.C., Palomino, J., de Valpine, P., Kremen, C., 2015. Diversification practices reduce organic to conventional yield gap. Proc. R. Soc. B Biol. Sci. 282, 20141396.

Portanguen, S., Tournayre, P., Sicard, J., Astruc, T., Mirade, P.S., 2019. Toward the design of functional foods and biobased products by 3D printing: a review. Trends Food Sci. Technol. 86, 188-198.

Potts, S.G., Imperatriz-Fonseca, V., Ngo, H.T., Aizen, M.A., Biesmeijer, J.C., Breeze, T.D., Dicks, L.V., Garibaldi, L.A., Hill, R., Settele, J., Vanbergen, A.J., 2016. Safeguarding pollinators and their values to human well-being. Nature 540, 220-229.

Pretty, J.N., 1997. The Sustainable Intensification of Agriculture. Natural Resources Forum. Wiley Online Library, pp. 247-256.

Pretty, J., 2018. Intensification for redesigned and sustainable agricultural systems. Science 362, eaav0294.

Pretty, J.N., Noble, A.D., Bossio, D., Dixon, J., Hine, R.E., Penning de Vries, F.W., Morison, J.I., 2006. Resource-Conserving Agriculture Increases Yields in Developing Countries. ACS Publications.

Pretty, J., Toulmin, C., Williams, S., 2011. Sustainable intensification in African agriculture. Int. J. Agric. Sustain. 9, 5-24.

Pywell, R.F., Heard, M.S., Woodcock, B.A., Hinsley, S., Ridding, L., Nowakowski, M., Bullock, J.M., 2015. Wildlife-friendly farming increases crop yield: evidence for ecological intensification. Proc. Biol. Sci. 282, 20151740.

Qaim, M., 2017. Globalisation of agrifood systems and sustainable nutrition. Proc. Nutr. Soc. 76, 12-21.

Queiroz, C., Beilin, R., Folke, C., Lindborg, R., 2014. Farmland abandonment: threat or opportunity for biodiversity conservation? A global review. Front. Ecol. Environ. 12, 288-296.

Rader, R., Bartomeus, I., Garibaldi, L.A., Garratt, M.P., Howlett, B.G., Winfree, R., Cunningham, S.A., Mayfield, M.M., Arthur, A.D., Andersson, G.K., Bommarco, R., Brittain, C., Carvalheiro, L.G., Chacoff, N.P., Entling, M.H., Foully, B., Freitas, B.M., Gemmill-Herren, B., Ghazoul, J., Griffin, S.R., Gross, C.L., Herbertsson, L., Herzog, F., Hipolito, J., Jaggar, S., Jauker, F., Klein, A.M., Kleijn, D., Krishnan, S., Lemos, C.Q., Lindstrom, S.A., Mandelik, Y., Monteiro, V.M., Nelson, W., Nilsson, L., Pattemore, D.E., de O. Pereira, N., Pisanty, G., Potts, S.G., Reemer, M., Rundlof, M., Sheffield, C.S., Scheper, J., Schuepp, C., Smith, H.G., Stanley, D.A., Stout, J.C., Szentgyorgyi, H., Taki, H., Vergara, C.H., Viana, B.F., Woyciechowski, M., 2016. Non-bee insects are important contributors to global crop pollination. Proc. Natl. Acad. Sci. U. S. A. 113, 146-151. 
Redhead, J.W., Woodcock, B.A., Pocock, M.J.O., Pywell, R.F., Vanbergen, A.J., Oliver, T.H., 2018. Potential landscape-scale pollinator networks across Great Britain: structure, stability and influence of agricultural land cover. Ecol. Lett. 21, 1821-1832.

Redlich, S., Martin, E.A., Steffan-Dewenter, I., 2018. Landscape-level crop diversity benefits biological pest control. J. Appl. Ecol. 55, 2419-2428.

Redpath, S.M., Bhatia, S., Young, J., 2015. Tilting at wildlife: reconsidering human-wildlife conflict. Oryx 49, 222-225.

Reganold, J.P., Wachter, J.M., 2016. Organic agriculture in the twenty-first century. Nat. Plants 2, 15221.

Ricketts, T.H., Regetz, J., Steffan-Dewenter, I., Cunningham, S.A., Kremen, C., Bogdanski, A., Gemmill-Herren, B., Greenleaf, S.S., Klein, A.M., Mayfield, M.M., Morandin, L.A., Ochieng, A., Viana, B.F., 2008. Landscape effects on crop pollination services: are there general patterns? Ecol. Lett. 11, 499-515.

Rigg, J., Salamanca, A., Thompson, E.C., 2016. The puzzle of East and Southeast Asia's persistent smallholder. J. Rural. Stud. 43, 118-133.

Rockstrom, J., Williams, J., Daily, G., Noble, A., Matthews, N., Gordon, L., Wetterstrand, H., DeClerck, F., Shah, M., Steduto, P., de Fraiture, C., Hatibu, N., Unver, O., Bird, J., Sibanda, L., Smith, J., 2017. Sustainable intensification of agriculture for human prosperity and global sustainability. Ambio 46, 4-17.

Rollin, O., Garibaldi, L.A., 2019. Impacts of honeybee density on crop yield: a meta-analysis. J. Appl. Ecol. 56, 1152-1163.

Rosenstock, T.S., Dawson, I.K., Aynekulu, E., Chomba, S., Degrande, A., Fornace, K., Jamnadass, R., Kimaro, A., Kindt, R., Lamanna, C., Malesu, M., Mausch, K., McMullin, S., Murage, P., Namoi, N., Njenga, M., Nyoka, I., Paez Valencia, A.M., Sola, P., Shepherd, K., Steward, P., 2019. A planetary health perspective on agroforestry in Sub-Saharan Africa. One Earth 1, 330-344.

Rudel, T.K., Kwon, O.J., Paul, B.K., Boval, M., Rao, I.M., Burbano, D., McGroddy, M., Lerner, A.M., White, D., Cuchillo, M., Luna, M., Peters, M., 2016. Do smallholder, mixed crop-livestock livelihoods encourage sustainable agricultural practices? A metaanalysis. Land 5, 6.

Rundlöf, M., Nilsson, H., Smith, H.G., 2008. Interacting effects of farming practice and landscape context on bumble bees. Biol. Conserv. 141, 417-426.

Rusch, A., Bommarco, R., Jonsson, M., Smith, H.G., Ekbom, B., 2013. Flow and stability of natural pest control services depend on complexity and crop rotation at the landscape scale. J. Appl. Ecol. 50, 345-354.

Rusch, A., Chaplin-Kramer, R., Gardiner, M.M., Hawro, V., Holland, J., Landis, D., Thies, C., Tscharntke, T., Weisser, W.W., Winqvist, C., 2016. Agricultural landscape simplification reduces natural pest control: a quantitative synthesis. Agric. Ecosyst. Environ. 221, 198-204.

Rusere, F., Crespo, O., Dicks, L., Mkuhlani, S., Francis, J., Zhou, L., 2019a. Enabling Acceptance and Use of Ecological Intensification Options Through Engaging Smallholder Farmers in Semi-Arid Rural Limpopo and Eastern Cape. Agroecology and Sustainable Food Systems, South Africa.

Rusere, F., Mkuhlani, S., Crespo, O., Dicks, L.V., 2019b. Developing pathways to improve smallholder agricultural productivity through ecological intensification technologies in semi-arid Limpopo, South Africa. Afr. J. Sci. Technol. Innov. Dev. 11, 543-553.

Samberg, L.H., Gerber, J.S., Ramankutty, N., Herrero, M., West, P.C., 2016. Subnational distribution of average farm size and smallholder contributions to global food production. Environ. Res. Lett. 11, 124010.

Sann, C., Theodorou, P., Heong, K.L., Villareal, S., Settele, J., Vidal, S., Westphal, C., 2018. Hopper parasitoids do not significantly benefit from non-crop habitats in rice production landscapes. Agric. Ecosyst. Environ. 254, 224-232. 
Schneider, M.K., Luscher, G., Jeanneret, P., Arndorfer, M., Ammari, Y., Bailey, D., Balazs, K., Baldi, A., Choisis, J.P., Dennis, P., Eiter, S., Fjellstad, W., Fraser, M.D., Frank, T., Friedel, J.K., Garchi, S., Geijzendorffer, I.R., Gomiero, T., GonzalezBornay, G., Hector, A., Jerkovich, G., Jongman, R.H.G., Kakudidi, E., Kainz, M., Kovacs-Hostyanszki, A., Moreno, G., Nkwiine, C., Opio, J., Oschatz, M.L., Paoletti, M.G., Pointereau, P., Pulido, F.J., Sarthou, J.P., Siebrecht, N., Sommaggio, D., Turnbull, L.A., Wolfrum, S., Herzog, F., 2014. Gains to species diversity in organically farmed fields are not propagated at the farm level. Nat. Commun. 5, 4151.

Schoenly, K.G., Justo, H.D, Barrion, A.T., Harris, M.K., Bottrell., D.G., et al., 1998. An analysis of invertebrate biodiversity in a Philippine farmer's irrigated rice field. Environ. Entomol. 27, 1125-1136.

Schoenly, K.G., Cohen, J.E., Heong, K.L., Litsinger, J.A., Barrion, A.T., Arida, G., et al., 2010. Fallowing did not disrupt invertebrate fauna in Philippine low-pesticide irrigated rice fields. J. Appl. Ecol. 47, 593-602.

Schrama, M., de Haan, J.J., Kroonen, M., Verstegen, H., Van der Putten, W.H., 2018. Crop yield gap and stability in organic and conventional farming systems. Agric. Ecosyst. Environ. 256, 123-130.

Settele, J., Settle, W.H., 2018. Conservation biological control: improving the science base. Proc. Natl. Acad. Sci. U. S. A. 115, 8241-8243.

Settle, W., Ariawan, H., Astuti, E.T., Widyastama, C., Arief Lukman, H., Hindayana, D., Lestari, A.S., 1996. Managing tropical rice pests through conservation of generalist natural enemies and alternative prey. Ecology 77, 1975-1988.

Seufert, V., Ramankutty, N., Foley, J.A., 2012. Comparing the yields of organic and conventional agriculture. Nature 485, 229-232.

Shackelford, G., Steward, P.R., Benton, T.G., Kunin, W.E., Potts, S.G., Biesmeijer, J.C., Sait, S.M., 2013. Comparison of pollinators and natural enemies: a meta-analysis of landscape and local effects on abundance and richness in crops. Biol. Rev. 88, 1002-1021.

Sigsgaard, L., 2000. Early season natural biological control of insect pests in rice by spidersand some factors in the management of the cropping system that may affect this control. European Arachnology. Aarhus University Press, pp. 57-64.

Specht, K., Siebert, R., Hartmann, I., Freisinger, U.B., Sawicka, M., Werner, A., Thomaier, S., Henckel, D., Walk, H., Dierich, A., 2014. Urban agriculture of the future: an overview of sustainability aspects of food production in and on buildings. Agric. Hum. Values 31, 33-51.

Springmann, M., Clark, M., Mason-D'Croz, D., Wiebe, K., Bodirsky, B.L., Lassaletta, L., de Vries, W., Vermeulen, S.J., Herrero, M., Carlson, K.M., Jonell, M., Troell, M., DeClerck, F., Gordon, L.J., Zurayk, R., Scarborough, P., Rayner, M., Loken, B., Fanzo, J., Godfray, H.C.J., Tilman, D., Rockstrom, J., Willett, W., 2018. Options for keeping the food system within environmental limits. Nature 562, 519-525.

Steffen, W., Persson, A., Deutsch, L., Zalasiewicz, J., Williams, M., Richardson, K., Crumley, C., Crutzen, P., Folke, C., Gordon, L., Molina, M., Ramanathan, V., Rockstrom, J., Scheffer, M., Schellnhuber, H.J., Svedin, U., 2011. The anthropocene: from global change to planetary stewardship. Ambio 40, 739-761.

Steffen, W., Rockstrom, J., Richardson, K., Lenton, T.M., Folke, C., Liverman, D., Summerhayes, C.P., Barnosky, A.D., Cornell, S.E., Crucifix, M., Donges, J.F., Fetzer, I., Lade, S.J., Scheffer, M., Winkelmann, R., Schellnhuber, H.J., 2018. Trajectories of the earth system in the anthropocene. Proc. Natl. Acad. Sci. U. S. A. $115,8252-8259$.

Stephens, N., 2013. Growing meat in laboratories: the promise, ontology, and ethical boundary-work of using muscle cells to make food. Configurations 21, 159-181. 
Steward, P.R., Shackelford, G., Carvalheiro, L.G., Benton, T.G., Garibaldi, L.A., Sait, S.M., 2014. Pollination and biological control research: are we neglecting two billion smallholders. Agric. Food Secur. 3, 5.

Swanton, C.J., Stephan, F.W., 1991. Integrated weed management: the rationale and approach. Weed Technol. 5, 657-663.

Tamburini, G., Bommarco, R., Kleijn, D., van der Putten, W.H., Marini, L., 2019. Pollination contribution to crop yield is often context-dependent: a review of experimental evidence. Agric. Ecosyst. Environ. 280, 16-23.

Therond, O., Duru, M., Roger-Estrade, J., Richard, G., 2017. A new analytical framework of farming system and agriculture model diversities. A review. Agron. Sustain. Dev. 37, 21.

Thomaier, S., Specht, K., Henckel, D., Dierich, A., Siebert, R., Freisinger, U.B., Sawicka, M., 2015. Farming in and on urban buildings: present practice and specific novelties of Zero-Acreage Farming (ZFarming). Renewable Agric. Food Syst. 30, 43-54.

Tittonell, P., 2014. Ecological intensification of agriculture-sustainable by nature. Curr. Opin. Environ. Sustain. 8, 53-61.

Tittonell, P., Giller, K.E., 2013. When yield gaps are poverty traps: the paradigm of ecological intensification in African smallholder agriculture. Field Crop Res. 143, 76-90.

Tixier, P., Peyrard, N., Aubertot, J.N., Gaba, S., Radoszycki, J., Caron-Lormier, G., Vinatier, F., Mollot, G., Sabbadin, R., 2013. Modelling interaction networks for enhanced ecosystem services in agroecosystems. In: Woodward, G., Bohan, D.A. (Eds.), Ecological Networks in an Agricultural World. Advances in Ecological Research, vol. 49. Elsevier, pp. 437-480.

Toledo, V.M., Barrera-Bassols, N., 2017. Political agroecology in Mexico: a path toward sustainability. Sustainability 9, 268.

Torralba, M., Fagerholm, N., Burgess, P.J., Moreno, G., Plieninger, T., 2016. Do European agroforestry systems enhance biodiversity and ecosystem services? A meta-analysis. Agric. Ecosyst. Environ. 230, 150-161.

Tscharntke, T., Clough, Y., Wanger, T.C., Jackson, L., Motzke, I., Perfecto, I., Vandermeer, J., Whitbread, A., 2012. Global food security, biodiversity conservation and the future of agricultural intensification. Biol. Conserv. 151, 53-59.

Tsiafouli, M.A., Thebault, E., Sgardelis, S.P., de Ruiter, P.C., van der Putten, W.H., Birkhofer, K., Hemerik, L., de Vries, F.T., Bardgett, R.D., Brady, M.V., Bjornlund, L., Jorgensen, H.B., Christensen, S., Hertefeldt, D.'.T., Hotes, S., Hol, W.H.G., Frouz, J., Liiri, M., Mortimer, S.R., Setala, H., Tzanopoulos, J., Uteseny, K., Pizl, V., Stary, J., Wolters, V., Hedlund, K., 2015. Intensive agriculture reduces soil biodiversity across Europe. Glob. Chang. Biol. 21, 973-985.

Tuck, S.L., Winqvist, C., Mota, F., Ahnström, J., Turnbull, L.A., Bengtsson, J., 2014. Landuse intensity and the effects of organic farming on biodiversity: a hierarchical metaanalysis. J. Appl. Ecol. 51, 746-755.

UN, 2015. Transforming Our World: The 2030 Agenda for Sustainable Development. UN DESA.

UN, 2019. World Population Prospects 2019: Highlights. ST/ESA/SER.A/423. United Nations Department of Economic and Social Affairs.

Vanbergen, A.J., Watt, A.D., Mitchell, R., Truscott, A.-M., Palmer, S.C., Ivits, E., Eggleton, P., Jones, T.H., Sousa, J.P., 2007. Scale-specific correlations between habitat heterogeneity and soil fauna diversity along a landscape structure gradient. Oecologia 153, 713-725.

Vanbergen, A.J., Espíndola, A., Aizen, M.A., 2018. Risks to pollinators and pollination from invasive alien species. Nat. Ecol. Evol. 2, 16-25.

Veen, C., Wubs, J., Bardgett, R., Barrios, E., Bradford, M., Carvalho, S., De Deyn, G., de Vries, F., Giller, K.E., Kleijn, D., 2019. Applying the aboveground-belowground interaction concept in agriculture: spatio-temporal scales matter. Front. Ecol. Evol. 7, 300. 
Vermeulen, S.J., Challinor, A.J., Thornton, P.K., Campbell, B.M., Eriyagama, N., Vervoort, J.M., Kinyangi, J., Jarvis, A., Läderach, P., Ramirez-Villegas, J., 2013. Addressing uncertainty in adaptation planning for agriculture. Proc. Natl. Acad. Sci. U. S. A. $110,8357-8362$.

Vermeulen, S.J., Dinesh, D., Howden, S.M., Cramer, L., Thornton, P.K., 2018. Transformation in practice: a review of empirical cases of transformational adaptation in agriculture under climate change. Front. Sustain. Food Syst. 2, 65.

von der Dunk, A., Grêt-Regamey, A., Dalang, T., Hersperger, A.M., 2011. Defining a typology of peri-urban land-use conflicts-a case study from Switzerland. Landsc. Urban Plan. 101, 149-156.

Waddington, S.R., Li, X.Y., Dixon, J., Hyman, G., de Vicente, M.C., 2010. Getting the focus right: production constraints for six major food crops in Asian and African farming systems. Food Sec. 2, 27-48.

Wagg, C., Bender, S.F., Widmer, F., van der Heijden, M.G.A., 2014. Soil biodiversity and soil community composition determine ecosystem multifunctionality. Proc. Natl. Acad. Sci. U. S. A. 111, 5266-5270.

Wall, D.H., Nielsen, U.N., Six, J., 2015. Soil biodiversity and human health. Nature 528, 69-76.

Way, M.J., Heong, K.L., 1994. Integrated biodiversity management in paddy fields: shift of paradigm from IPM toward IBM. Bull. Entomol. Res. 84, 567-587.

Westphal, C., Vidal, S., Horgan, F.G., Gurr, G.M., Escalada, M., Van Chien, H., Tscharntke, T., Heong, K.L., Settele, J., 2015. Promoting multiple ecosystem services with flower strips and participatory approaches in rice production landscapes. Basic Appl. Ecol. 16, 681-689.

Wezel, A., Casagrande, M., Celette, F., Vian, J.F., Ferrer, A., Peigne, J., 2014. Agroecological practices for sustainable agriculture. A review. Agron. Sustain. Dev. $34,1-20$.

Wheeler, T., von Braun, J., 2013. Climate change impacts on global food security. Science 341, 508-513.

Willett, W., Rockstrom, J., Loken, B., Springmann, M., Lang, T., Vermeulen, S., Garnett, T., Tilman, D., DeClerck, F., Wood, A., Jonell, M., Clark, M., Gordon, L.J., Fanzo, J., Hawkes, C., Zurayk, R., Rivera, J.A., De Vries, W., Sibanda, L.M., Afshin, A., Chaudhary, A., Herrero, M., Agustina, R., Branca, F., Lartey, A., Fan, S.G., Crona, B., Fox, E., Bignet, V., Troell, M., Lindahl, T., Singh, S., Cornell, S.E., Reddy, K.S., Narain, S., Nishtar, S., Murray, C.J.L., 2019. Food in the Anthropocene: the EAT-Lancet Commission on healthy diets from sustainable food systems. Lancet 393, 447-492.

Winfree, R., Kremen, C., 2009. Are ecosystem services stabilized by differences among species? A test using crop pollination. Proc. R. Soc. B Biol. Sci. 276, 229-237.

Winfree, R., Fox, J.W., Williams, N.M., Reilly, J.R., Cariveau, D.P., 2015. Abundance of common species, not species richness, drives delivery of a real-world ecosystem service. Ecol. Lett. 18, 626-635.

Winfree, R., Reilly, J.R., Bartomeus, I., Cariveau, D.P., Williams, N.M., Gibbs, J., 2018. Species turnover promotes the importance of bee diversity for crop pollination at regional scales. Science 359, 791-793.

Wintermantel, D., Odoux, J.-F., Chadœuf, J., Bretagnolle, V., 2019. Organic farming positively affects honeybee colonies in a flower-poor period in agricultural landscapes. J. Appl. Ecol. 56, 1960-1969.

Wolfert, S., Ge, L., Verdouw, C., Bogaardt, M.J., 2017. Big data in smart farming-a review. Agr. Syst. 153, 69-80.

Woodcock, B.A., Edwards, M., Redhead, J., Meek, W.R., Nuttall, P., Falk, S., Nowakowski, M., Pywell, R.F., 2013. Crop flower visitation by honeybees, bumblebees 
and solitary bees: behavioural differences and diversity responses to landscape. Agric. Ecosyst. Environ. 171, 1-8.

Woodcock, B.A., Bullock, J.M., McCracken, M., Chapman, R.E., Ball, S.L., Edwards, M.E., Nowakowski, M., Pywell, R.F., 2016. Spill-over of pest control and pollination services into arable crops. Agric. Ecosyst. Environ. 231, 15-23.

Woodcock, B.A., Garratt, M.P.D., Powney, G.D., Shaw, R.F., Osborne, J.L., Soroka, J., Lindström, S.A.M., Stanley, D., Ouvrard, P., Edwards, M.E., Jauker, F., McCracken, M.E., Zou, Y., Potts, S.G., Rundlöf, M., Noriega, J.A., Greenop, A., Smith, H.G., Bommarco, R., van der Werf, W., Stout, J.C., Steffan-Dewenter, I., Morandin, L., Bullock, J.M., Pywell, R.F., 2019. Meta-analysis reveals that pollinator functional diversity and abundance enhance crop pollination and yield. Nat. Commun. 10, 1481.

Yu, X., Heong, K.L., Hu, C., Barrion, A.T., et al., 1996. Role of non-rice habitats for conserving egg parasitoids of rice planthoppers and leafhoppers. In: Hokyo, N., Norton, G. (Eds.), Proceedings of the International Workshop on Pest Management Strategies in Asian Monsoon Agroecosystems. Kyushu National Agricultural Experimental Station, Ministry of Agriculture, Forestry and Fisheries; Kumamoto, Japan, pp. 63-67.

Zasada, I., 2011. Multifunctional peri-urban agriculture-a review of societal demands and the provision of goods and services by farming. Land Use Policy 28, 639-648.

Zhu, X.G., Long, S.P., Ort, D.R., 2010. Improving photosynthetic efficiency for greater yield. In: Merchant, S., Briggs, W.R., Ort, D. (Eds.), Annual Review of Plant Biology. vol. 61. Annual Reviews.

Zimmerer, K.S., Carney, J.A., Vanek, S.J., 2015. Sustainable smallholder intensification in global change? Pivotal spatial interactions, gendered livelihoods, and agrobiodiversity. Curr. Opin. Environ. Sustain. 14, 49-60.

Zougmore, R.B., Partey, S.T., Ouedraogo, M., Torquebiau, E., Campbell, B.M., 2018. Facing climate variability in sub-Saharan Africa: analysis of climate-smart agriculture opportunities to manage climate-related risks. Cah. Agric. 27, 34001. 